\title{
Integration of Psyche and Matter and Sandplay Therapy in the Era of Pandemic (Mask, Tal) ${ }^{*}$
}

\author{
Mikyung Jang**
}

In this paper, the symbolic meaning of the pandemic and the role of the sandplay therapist in integration of psyche and matter were attempted to be understood from an analytical psychology perspective. Traditionally, in Korean culture, when an epidemic spreads, mask dance plays such as Byeolshin Tal Chum Gut Nori, which is a shamanistic mask dance where individuals play, and rituals such as these were offered to appease the gods who brought diseases, hoping the god would leave minimal damage while the people waited for it to pass. In that sense, the expression 'Byeolshin' refers to both a god and a contagious disease: smallpox as a pandemic in ancient times. The use of the mask, tal, in these shamanistic mask dance plays and rituals is related to the meaning of the 'mask'. The word "mask" in Korean means mask, but it is also a word that means diseases, problems, breakdowns, shortcomings, difficulties, etc. Also, the "playing" is an interesting part of the ritual, which means that playing has a healing effect and is a way to appease the archetypal fears and anxieties caused by the divine plague. Just as our traditional culture did, in the era of the corona pandemic (mask, mask), sandplay therapists are in a time and situational position to play a role in making clients realize that matter and psyche/spirit, that is, external things, are internal projections. This is because sandplay therapy is a way of playing and a ritual, and it is a symbolic and healing approach that allows each person to meet their inner 'god', that is, their true Self. This process must occur first in the therapist, and only the therapist who has experienced such a process can understand the client's process in terms of the archetypal transferencecountertransference relationship. Also, it tries to explain the archetypal fear of the pandemic by linking it with the personal complex, and the symbol of the pandemic that appears in sandplay therapy was presented along with the symbols of the earthquake disaster in Nepal.

Keywords : Corona, pandemic, mask, tal, play, sandplay therapy, integration of matter and psyche

* Funding for this paper was provided by Namseoul University year 2021.

** Professor, Namseoul University, Department of Child Welfare (jangmiky@nsu.ac.kr) 
Journal of Symbols \& Sandplay Therapy, Vol.12 No.2.

\section{I . Introduction}

Rather than clinging to material things or external objects, accepting them as a symbol of the inner projection and trying to find its symbolic and personal meaning in the inner spirit is the work of integrating matter and psyche, which is the goal of sandplay therapy work (Steinhartd, re-cited by Jang Mikyung, 2017; Kalff, 1980). The cause of the Corona pandemic is still unknown, but one thing is clear: it will be a signal to look inside from an attitude of life that has overly focused on external things such as success, achievement, wealth, honor, status, recognition, and satisfaction. This is because it is the result of man's excessive control over nature and his attempts to gain more power. The rapid change of technological civilization in the era of the 4th industrial revolution and the pandemic of the virus are acting as a phenomenon of archetypal projections that stimulate the primal anxiety of mankind more than ever before. The expression 'archetypal' is used because the meaning of the pandemic is related to life and death due to disease (absolute thing), which makes us ask questions about fear, horror, anxiety, uncertainty, out of control, and furthermore, the meaning of existence in this era. No one knows what the ultimate outcome of this situation will be. However, it is clear that what it means, and what it requires to us, is a change in our attitudes toward life and a sign that calls for attention to what we have been neglecting. This perspective on the pandemic reflects the theoretical perspective of analytical psychology, which attempts to see both external and material things from an intrapsychic perspective (Jacobi, 2013).

In situations such as the pandemic, most people experience anxiety and fear, but clients who come to a psychotherapist may be in a more serious situation. In particular, clients who have had psychological and relational vulnerabilities, i.e., negative personal complex, even before the outbreak of Corona may be more negatively affected by the Corona pandemic. This is true for child and adolescent clients as well as adult clients. Psychotherapists know too well how children and adolescents have suffered from the standards, expectations and demands of adults. Adults sacrifice their inner world by forcing one-sided attitudes and values resulting from the greed of adults to individuals who cannot resist on their own. As a result, our society has the title of the highest youth suicide rate in the world, and the youth suicide rate in 2020 compared to 2017 was the highest compared to other age groups (New Daily Economy, 2020). There is a question of whether all children and adolescents can do this on their own, but fortunately, like 
the BTS phenomenon, adolescents with the ability to intuitively reflect on their life are exerting influence to make other adolescents struggle to find their own life. These changes in the times make the psychotherapist think about what role changes are required in the face of a new era.

In this paper, to understand the relationship between what is happening in the human spirit and what is happening in the physical world, the symbolic meaning of the pandemic was interpreted from an analytical psychology perspective. In the same context, sandplay therapy in the era of pandemic (tal, mask), that is, sandplay therapy as a method of integrating matter and psyche in terms of simultaneity, and the role of sandplay therapist were discussed. We also attempted to integrate the archetypal anxieties of the pandemic and personal complexes for explanation, and presented the symbol of the pandemic that appears in sandplay therapy along with other disaster symbols by viewing the pandemic as a kind of disaster.

Why is the era of the pandemic an era of "mask" and what is its symbolic meaning? In a word, the pandemic can be summarized as words meaning that something is wrong. Fears such as fear, destruction, and death are archetypal because they are absolute, fundamental, and divine. That is, although the divine thing can also cause positive emotional experiences such as impression, holiness, and ecstasy, the archetypal experience can have a strong and negative effect that is unavoidable by human power. In other words, tal of the pandemic is the archetypal shadow of our times. It is a larger shadow than the black swan, a symbol of individual shadow (Stein, 2020a, 2020b). 'Tal' means 'Mask' in Korean. In addition to the meaning of covering the face like a mask, a mask is used to mean several other things, such as epidemic, mental and physical illness, breakdown of machinery or tools, bad habits or faults of people, accusations, negative accidents, complaints and grumbling, social problems or contradictions (Lim Jae-hae, 1999). The examples include expressions such as 'that person has such a problem' or 'it looks like it will go wrong'. Therefore, if you look at dance, theater, gut and Tal Chum Gut Nori (masked dance play) wherein rituals are performed for the gods while wearing masks, you can see the culture, society and the problems of the individuals who belong to them. In the tradition of Andong Hahoe Byeolshin Gut Mask Nori, a traditionally performed mask dance, the word 'byeolshin' also refers to a disease caused by a virus called Mamasin, Guest, and smallpox (Lee Bu-yeong, 1986), an infectious disease that killed tens of thousands of people, and furthermore, it means various masks that exist in life, just like diseases. To modern people, smallpox sounds like a disease that existed only in primitive times. To that extent, our era has 
Journal of Symbols \& Sandplay Therapy, Vol.12 No.2.

believed that we have conquered and could control nature such as viruses and bacteria. At present, however, the expanded ego of humans who believe they can dominate and control nature is helpless in the face of nature's 'revenge,' such as the Corona pandemic. Literally, it went wrong. A virus that is small enough to be invisible to mankind, who was proud that mankind's scientific ability would conquer viruses, is challenging the pride of mankind who put science above religion and tried to prove religion with science (Wilber, 2020).

The problem in an analytical psychology perspective is that an individual is disconnected from his/her inner life. It is blocking their ears to the 'call of their inner, that is, their own nature' to live their whole life. Nature may get 'revenge' by creating airway obstruction for blocking the material nature and our inner nature so that we cannot find a place to breathe. Some say that the corona virus is caused by intentional spread in a biochemical laboratory, accidental leakage, conspiracy theories, or use of wild animals for food. Whatever the cause, however, it can be said to be the revenge of nature resulting from the arrogance that humans can use nature recklessly and control the forces of nature. In other words, it is the archetypal shadow of our times that goes beyond the black swan, which is an individual shadow. Just as we think things so small that they cannot be seen cannot do anything to humans, humans downplay the subtle voice of the invisible inner nature. In the same vein, Freddie Taborda mentioned that dyspnea and a sharp drop in blood oxygen levels, the most serious symptoms caused by the coronavirus, have psychological symbolism (Taborada, 2020). It means that our way of life is asphyxiating. From the perspective of the collective unconscious, we have a suffocating attitude toward life: we must be doing well at school, we must succeed, we must have more wealth, we must be competent, we must not be inferior, we must be first to be worthy, we have to be seen as a good person, we have to be the perfect parent, we must have broad relationships, we must be loved and so on. Because of their failure to do so, some people cannot sleep at night because they push themselves to do better, suffer from guilt, or worry that something bad might happen to them or their children. Furthermore, they lose their sense of direction in life and are afraid. What an asphyxiating life. Some people dismiss the corona virus as a conspiracy to escape from such anxiety and worry as a defense mechanism. Murray Stein describes these people as those in the era of the pandemic who are afraid to see themselves and want to see the outside world through all kinds of media (Stein, 2020a). He also said that the corona is the shadow of the archetypal god, Umbra Mundi, and the shadow of the archetypal god causes 
shudder, mysterious fear, and that there is no way to overcome the invisible corona virus except by looking at the invisible inner world. In Jungian work we encourage our clients to work with their symbolic images in a similar way - to attend to them, to speak with them, to listen to them (Stein, 2020b). This is a symbolic work method integrated with your inner self. These work methods include active imagination, which was first used by Jung, as well as various types of meditation, prayer, sandplay therapy, and dream analysis.

Since our ancestors were wise, they knew what to do when they became ill or when they were about to become ill. When they became ill, they danced and played with all their heart to please and appease the gods (inner side) so that the illness could pass leaving minimal damage, and offered rituals to the gods. They thought that the epidemic was caused by the gods. That is why it is called Byeolshin Tal Chum Gut Nori. While wearing masks and performing rituals such as plays and rituals to the gods, they not only appeased the shadow of the archetypal gods who caused primal anxiety and fear, but also responded to the fear and anxiety of death through a sense of solidarity with fellow humans and collective self-response through mask plays and rituals. That is the reason why Jung did artistic symbolic work with his patients and described Jung's own fantasy work in the Red Book (Jung, 2009).

When someone becomes ill from something such as a pandemic (archetypal), the individual's psychological complex (the part that was 'dead' without being integrated into consciousness) is activated and tends to aggravate the symptoms (Rhi, 2012). The impact of archetypal events such as pandemics or disasters such as earthquakes, that is, what the archetype will do to the individual, either creative or destructive, is determined by how much the ego has the ability to integrate the contents of the unconscious and how strong emotional complexes (personal complexes) in the unconscious are repressed and prepared to be expressed at the moment (Rhi, 2012, p. 369). As mentioned above, like traditional Tal Chum Gut Nori, a kind of artistic ritual such as play, dream, art, gut, and prayer also has a function in terms of preventing the limitations of the ego from collapsing. Sandplay therapy has performed such a function, and such function should be strengthened in the future. This will be described in detail later.

According to Rhi, the smallpox god and the soul of the dead are different. The smallpox god is closely related to the archetype of the collective unconscious, and the soul of the dead is related to the individual unconscious or individual complex. Rhi (2012, p. 208) said that the smallpox god Samseunghalmang caused smallpox in Jeju Island, Korea, and that smallpox means 
Journal of Symbols \& Sandplay Therapy, Vol.12 No.2.

passing through the body over a period of time, in that people thought that the nonsense of a child suffering from smallpox was the voice of God and that the scars on his/her face were the footprints of the god. This is like a corona virus passing through the body for a period of time. This is not the same as the soul of the dead (personal complex) entering the body (consciousness) of the living and causing problems. Samseunghalmang, a smallpox god, is the archetypal Great Mother, a kind of medical god, and has the duality of giving and healing diseases. Since the souls of the dead are the souls of the dead without living their lives according to their destiny, that is, they are parts of the human spirit that are not lived out, they are not properly integrated into consciousness and formed into a person, and are suppressed, so this part needs to be appeased and integrated. Otherwise, they will harm living humans. In other words, the fact that the souls of the dead do not go to their proper place and remain among the living means that there are strong emotions that cannot be consciously integrated (Rhi Bu-young, 2012, p. 431). This is proven by the fact that there are many stories of the souls of the dead that harass the living around the world, and that rituals and gut are constantly performed to relieve their anger. The ultimate purpose of various rituals and taboos for the dead is to achieve wholeness for the unfinished life (Rhi Bu-young, 2012, p. 431). If an unresolved personal complex is strongly acting on an individual, situations that cause archetypal fear, such as a pandemic, further weaken the vulnerable ego that is controlled by the strong complex. Therefore, it is necessary to separate the individual complex from the collective unconscious complex and integrate it into consciousness.

1. Sandplay therapy in the era of pandemic (tal, mask): the integration between matter and psyche

Then, it is necessary to discuss the role of the sandplay therapist, who is a psychotherapist, in times of archetypal phenomena such as a pandemic. It has to do with what to do or what not to do. A psychotherapist himself/herself may have to cover his/her face, which is a real persona, with a tal (mask). In other words, we are living in an era in which we have to show our true persona modestly by wearing a mask on our face, and please God by playing to let tal (illness) pass by.

Sandplay therapy is a psychotherapeutic approach that integrates the human spirit, the 'soul', 
with the matter to become one with the inner self (although many sandplay therapists try to match the inner world with the outside world). Solitude, silence, and introversion without denying fear and anxiety are the ways to do this. Since most clients cannot do this alone, they receive psychotherapy until they are able to do it on their own. Most people cannot do this because the way they have been living so far makes it a difficult experience for them. We are now in a situation where we are forced to do so. That may be the psychological meaning of the pandemic (Taborda, 2020). People say they are forced to stay at home longer than in the past, doing things that were less important before COVID-19, such as taking a walk, reading a book, spending time with family and cooking. Solitude gives each person an opportunity to integrate with their self through images, emotions, and thoughts that come to mind. For insight (individuation), therefore, we need to get acquainted with the things that come to mind. Silence calms us from the troublesome fuss and stress of the mind (Steinhardt, cited by Jang Mikyung 2017). The direction of all this introversion is the direction of the energy flow that integrates with the true self within the individual. This, without emphasizing, explains to clients why sandplay therapy work is necessary. This means that not only in the treatment room, but ultimately, the therapist and the client should be able to do it on their own by themselves. As already mentioned, this work must start from inside of the therapist. In order to heal the wounds of others, the therapist himself/herself needs to make an effort to integrate with the inner self. We need a therapist as a wounded and healed therapist, not a wounded therapist (Jung, 1935; Sedgwick, 2001).

It is interesting to note that the mask dance was a way to appease the gods and allow the disease to pass. In Tal Chum Gut Nori (mask dance), Nori has the same meaning as playing, and it refers to a group of people having fun or such an activity, and is also a general term for traditional Korean banquets such as gut, pungmul, and puppet shows (Standard Korean Dictionary, National Institute of the Korean Language). As shown in this meaning, you can see that playing is an art. Therefore, our mask dance is included in human artistic activity. Sandplay therapy may or may not be included in expressive arts therapy. However, since the expression of expressive art therapy has been used as a term to refer to a specific art therapy, it would be more appropriate to include it in 'creative' art therapy in terms of art in a broad sense to avoid misunderstanding. Creative art therapy is a therapeutic approach that focuses on creating meaning, empowerment, identity, emotional expression, multisensory communication, 
Journal of Symbols \& Sandplay Therapy, Vol.12 No.2.

relationship formation, and intersubjectivity (Leavy, 2015). Since everyone has an archetypal impulse to achieve self-realization (individuation, wholeness) through art in a broad sense, it should be understood as art in a broad sense, not art as the exclusive property of professional artists. Also, if photoshop or digital imaging techniques are included in the art expression genre, there is no reason why sandplay therapy should not be included in the artistic psychotherapy approach. Regarding art, Jung said that each person has an artist archetype inside, so not only arts such as art, music, etc., but also true art in a broad sense, comes from the soul. He also said that when you are chased by life in one direction, the energy of life is lost, or you are in a crisis of the times or situation, it shows the image symbols of another way of life, so you need to work on the inner side, and he did the same as mentioned above (Jung, 2009).

Regarding the meaning of creating works for artists, Jung said that art work is a fundamental experience given through fantasy (fantasy, that is, image symbol). Fantasy is not just beautiful, but among the fantasies that break through consciousness, there are also those that take people into strange and dark chaos and shock the individual. But even if it is scary and chaotic, if you take it seriously, it leads those engaged in 'creation' into another world.

Jung explained that the archetypal image experience as a primordial experience, and the primordial experience seems to come from the depths of pre-human times or nature transcending time, space, and culture. He also said that it is an experience in which human nature is vulnerable and there is a danger of being overwhelmed by its power if we do not know anything about its operation (Jung, 1966/2004, p.161), but if we deal with this experience courageously, the energy from the unconscious expands and matures our personality, and maintains true life and life (Jung, 1933/1955). This is why art is used as a healing method. This is because true art does not arise voluntarily from our will and ego, but from our unconscious. If the self-consciousness is too strong, one only tries to follow the will of the ego, but is unaware of the message from the unconscious or ignores it as a meaningless imagination. We need to listen to the symbolic image that comes from the unconscious because, as Jung mentioned, there is another layer of the human psyche that exists autonomously with one's own will regardless of consciousness. Jung called this the action of the psyche or soul (Jung, 1933/2017). According to Jung, the source of an art work is the soul, which is the matrix and source of all human activities, including human art and science (Jung, C. G. translated by Translation Committee for Jung's Works, 1966/2004, p. 156). Jung said that the soul is a 
substance constituting human life together with the body, and that it is a layer of the mind expressing the physical process that people experience while living in the world through a series of images. Archetypal events such as pandemics and natural disasters become symbolic events that project the things of the collective unconscious, and the projection of the collective unconscious sometimes makes us feel absolute emotion, but it activates the previously dormant personal complex, making us fall into fear, anxiety, and horror.

This is the same principle as that of the sandplay therapy work. In order to quiet our ego will for a while and to listen to the messages of our unconscious through our hands and images, we use the method of silence for psychotherapy. Silence means letting go of your ego will or obsession. Hearing the message of the unconscious through this 'art work' makes us commune with our inner fundamental being, and this communion changes our lives fundamentally. This theoretical context supports why the artistic approach, including sandplay therapy, has a function of healing and integrating matter and the human spirit in the age of tal (masks). In an article titled Art in a Time of Global Crisis: Interconnection and Companionship together with Art and Psyche, the Archive for Research in Archetypal Symbolism (ARAS) explained the need for artwork for interconnection and humanity's companionship in times of a pandemic crisis. At the same time, he emphasized the need for artistic image work in order to have hope despite companionship, resilience, risk and fear in the era of global crisis, despite differences in geographic distance, culture, and lifestyle. These groups are also asserting the need for material connection in the era of isolation and distancing.

People tend to regard imagination and fantasies as insubstantial and useless. However, Jung mentioned that it is not insubstantial, but is intrinsically a "subtle body" that is half physical and half mental (something corporeal, a "subtle body", semi-spiritual in nature (Jung, 1955). 12004, p. 277). The reason is that the way the unconscious communicates with the consciousness is not the language and logic we use in our daily life. The unconscious communicates using imagination (illusion, fantasy). The messages of the unconscious, activated by the symbol image method, are necessarily projected onto the outside world (whether it is a person, a thing, or a situation). Therefore, the imagination is a rich extract from both physical strength with life and archetypal force. (Vera imagination) has the power to inform the consciousness of the unconscious (This illusion might be well be the vera imaginatio possessed of "informing" power (Jung, 1953/1993, p. 252). Jung created a method of treating patients by relying on the power 
Journal of Symbols \& Sandplay Therapy, Vol.12 No.2.

of imagination, which is active imagination. He gave patients a task in which they should expand or develop the image or association of dreams into a free imaginative activity. This was done in various ways depending on the individual's aptitude or talent. While repeating this work, Jung discovered specific themes and morphological elements in the imaginary activities of his patients, and found that they appear repeatedly in many people. He found out chaos, duality, light and darkness, up and down, left and right opposites, a third thing that transcends oppositions, quarternity such as a square and a cross, a sphere or a circle, centering/ centroversioning where energy is concentrated. centering/centroversioning) and radiation-shaped constellations. Ultimately, it reminds us of a Mandala symbolizing self. There are countless numbers of examples of similar concrete forms, which are commonly found in the sandplay therapy scene. Through this work and works of his other methods, Jung suggested that there is a certain basic structure - the prototype - that brings about universal human behavior and reveals it through imaginary forms (Jung, 1956/1990b).

In addition to the pandemic, natural disasters such as earthquakes are archetypal phenomena that evoke images of religion or gods and cause primal anxiety and fear from an analytical psychology perspective. The fact that the image of God emerges or becomes a point of interest in it in times of crisis is the arrangement of the functions of especially the self archetype of the collective unconscious, to maintain the balance of the spirit (Jung, 1981). Natural disasters and the resulting self- archetypal energy are experienced as gods, and paradoxically, in order to prevent ego functions from overflowing with this archetypal energy, humans need the image of gods. The archetype is the primordial and structural element of the human soul (Jung, 1970). According to Jung, "Archetype...present themselves as ideas and images, like everything else that becomes a content of consciousness (Jung, 1981, p. 227)." For example, it can be symbolized as lion, dragon, old wise man, children (including hero children), mothers (Primordial Mother, Earth Mother, and virgins as transcendent personality (Jung, 1956/1990b). In particular, the self-archetype, which corresponds to the central archetype among the archetypes, tends to be symbolized as nature, specific shapes such as squares or circles, precious objects such as jewels, healing potions, kings, heroes, prophets, saviors, gods, etc. in the sandplay, projecting myths, fairy tales, dreams and fantasy images onto figures (Jung, 1971, p. 460). This experience of the self has the sacredness of religious revelation. Therefore, Jung noted that there is no intrinsic difference between the self as an empirical and psychological reality and the traditional concept 
of god (Jung, 1971). Self-archetype is an archetype that works to make each person unique, a true individual, that is, to achieve the wholeness of personality, and is the center of control and is a transcendent force that transcends the ego (Jung, 1970). When self-energy is connected to the ego, internal, psychological, and polar conflicts are integrated. However, all archetype patterns have a polarity. That is, one pole is positive and life-promoting, the other side is negative and life-destroying (Jung, 1956/1990b). In other words, it has both a creating, developing and caring side and a destructing side. It is similar to the fact that Shiva, one of the symbolic images of the self-archetype, has two aspects: destruction and creation.

Jung said that there are countless rituals performed for the sole purpose of defending oneself from an unexpected and dangerous overflow of the unconscious (Jung, 1964). Those refer to religious ceremonies created to appease the gods in order to protect humans from natural disasters that are considered divine and divine wrath (Rhi Bu-young, 2012). Also, humans have built religious buildings where religious ceremonies can be performed. As mentioned earlier, in Korean culture, rituals were performed to appease the gods when natural disasters or infectious diseases occurred or there are signs of an outbreak (Jang Mikyung, 2015). The Japanese, who suffered frequent sea-related natural disasters, built shrines on the beaches (Kawai, 2015), and Nepal is a landlocked country without seas, so they built small temples in villages and private homes as well as in nature, not on the coast, and there were numerous solar terms related to religion (https://en.wikipedia.org/wiki/Nepal). Therefore, their lives cannot be separated from God. Although there is no sea, Nepal has the Himalayas, with the world's highest peaks, and they experienced the vastness of the Himalayas itself or the immense power of nature associated with the Himalayas. This seems to have led to the perception that God exists in nature or nature itself (Jang Mikyung, 2015). It can be assumed that those who have experienced or witnessed earthquakes and the resulting loss of lives and livelihood perform such magical rituals, perhaps personally, by taking advantage of images of the gods in various symbolic ways. God and the temple can be compared to the self in analytical psychological psychotherapy. Just as humans can protect human civilization only by following the greatness and pure reason of nature, following the message of the inner self (Self) prevents the collapse of the self. Otherwise, we will be "retaliated" from nature, from God, or from within

In the so-called most "civilized advanced countries", most of the functions of the above-mentioned religions, rituals, and initiation rites have disappeared or their value is being 
Journal of Symbols \& Sandplay Therapy, Vol.12 No.2.

depreciated. Sandplay therapy should function like that for those who are disoriented and afraid. In other words, we have to play in the sandtray just like our ancestors played Tal Chum Gut Nori in the eras of the epidemics.

\section{Pandemic symbolism in the sand scene: How are the archetypal fear and} personal complex of the pandemic symbolized in the sandplay therapy?

In the sandplay therapy, immediately after an earthquake where thousands of people died, Nepalese clients described natural disasters such as earthquakes, destruction of life, and fear of the future as the earthquake itself, volcanic eruption, invasion of aliens, attack by primitive animals such as giant snakes or dinosaurs, a world destroyed or wiped out due to epidemics, scenes where everyone dies because of a war, everyone dies because of illness, or when an animal or monster invades and everyone dies (Lee Se-hwa \& Jang Mikyung, 2020). How should the sandplay therapist understand these scenes? These scenes are also an unconscious way of expressing inner disaster. They faithfully follow the principle of sandplay therapy. As shown in the Nepal earthquake study, it is worth paying attention to the wider symbolized ones, rather than directly using the corona figure or linking only the cases mentioned as corona. Interestingly, Kawai's sandplay therapy study also reported that it was more difficult to overcome the psychological trauma caused by the disaster when the Great East Japan Earthquake was described or mentioned as it is (Kawai, 2019).

It is necessary to see how the figure or sand scene selected by client's psyche is related to the client's personal complex and how the personal complex is linked to the anxiety that seems to be caused by the corona virus. Furthermore, in order to prevent the ego from being disturbed by external events, we need to realize that there is a greater being, an essential being, within us and share how to follow its message. That is the way to integrate the matter and the inner world. It means that clients, who feel anxious and deprived of their peace of mind by things outside the spirit, believing that things outside (success, achievement, acquisition, etc.) will bring them peace and struggle to get them, came to the therapist as the power of the complex became negatively stronger due to the absolute anxiety of the pandemic. The therapist should know what the outside world means to the individual. The power of the ego alone cannot change the essential existence within. We only conform to our nature, our true self. We cannot 
stop earthquakes, nor can we prevent viruses so small that they cannot be seen from mutating and taking millions of lives. Like our ancestors, we appease it with the ritual of playing, hoping that it passes as quietly as possible.

\section{Disaster symbols appearing in sandplay therapy}

\section{1) Corona symbol}

The following sand photo is an example of how the impact of a pandemic becomes stronger when it is connected with a child who has experienced a trauma that makes the impact of the archetypal event called a pandemic challenging for the self.
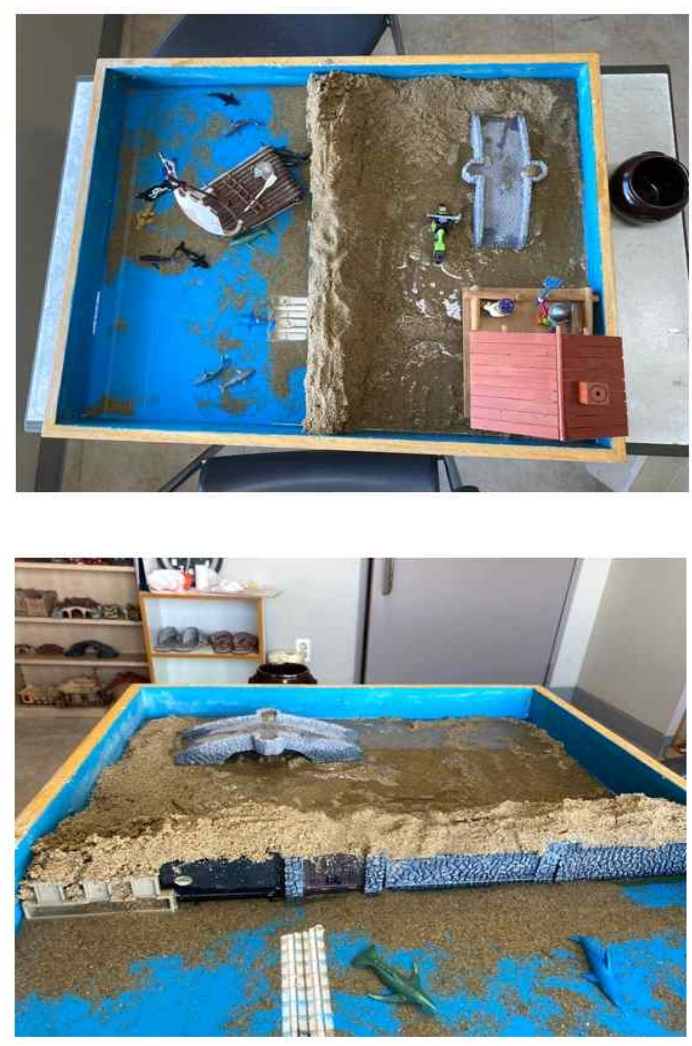

7-year-old girl 
Journal of Symbols \& Sandplay Therapy, Vol.12 No.2.

The client, a 7-year-old girl, was sexually harassed by a young man shortly before entering the house after she got off the kindergarten bus during the early days of COVID-19. She has since been criticized by her parents for not stopping him, not yelling, and not telling her parents right away. For this child, the outside world has become a very terrifying world where there are incomprehensible people, called molesters, as well as Corona. Since then, she has felt the fear of being followed by a zombie, which is clearly expressed in the sandplay scene. The most impressive thing about this child's sand photo is the wall like an impregnable fortress built to keep sharks out. If the wall looks strong, it may mean that the intensity of anxiety is great. Of course, it also means the potential power exists to build a strong wall. Since there is a scary shark that may come over at any time in the sea beyond the wall, she focused on building a strong wall. She did not feel relieved just by building a wall made of sand, so she even made a support with a fence. The child said that she ran to several places to keep the shark from chasing her, but it still followed her, so she built this wall. In this case, the shark symbolizes the archetypal power of the event, called the corona pandemic, on the individual. In the world to the right of the sea, there is everyday life. Even the house, which is one of the symbols of everyday life, has a strong fence. As the session progressed, the shark turned into Corona. It has changed to a story about people running away from Corona. In this case too, the overlap between the corona pandemic and other trauma or negative complexes in everyday life makes the impact of the pandemic even more negative.

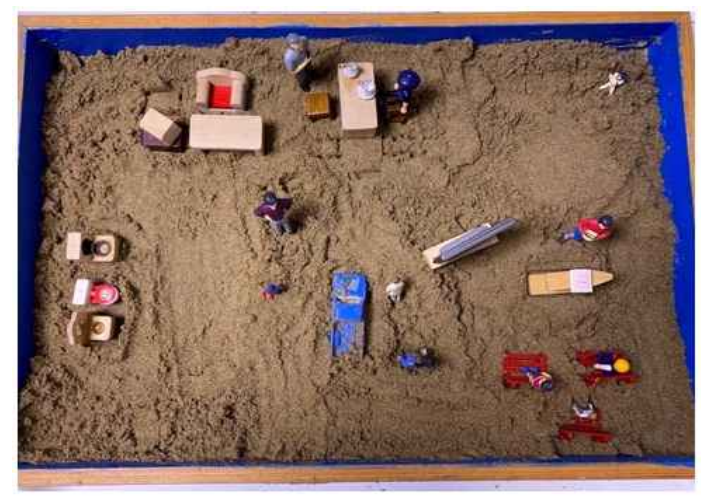

4th grade girl 
This photo is a sand photo of a 4th grade elementary school girl. This child was repeatedly sexually abused by her cousins over a relatively long period of time, and her parents reported it after the coronavirus outbreak. Nevertheless, there was no explanation or apology as to why this happened because the perpetrators were relatives. The child's mother had an obsession with cleaning. She was under a lot of stress from her mother about her usual cleanliness, which caused this child to develop a negative complex in which human relationships were constrained and oppressive. This sand photo shows the hygiene check process that one must go through in the house, and from school to classroom, in a very detailed and organized manner and making sure to follow the rules in order. The outbreak of COVID-19 reinforced and justified her mother's obsession with cleaning, heightened her anxiety, and made her more strongly control her child. The child, who has started puberty, has less evidence to assert her autonomy and independent daily life. Interestingly, this child chose wet sand. Wet sand gets on your hands and does not come off easily. As can be seen in the photo, the child touched the sand and moved the figure with the sand. There is even a car figure partially buried in the wet sand. In that sense, this child shows the process of overcoming the anxiety and fear that have become stronger due to the mother's obsession with cleaning and the corona virus.

\section{2) Earthquake Symbols}

Here are some sand photos that do not symbolize corona, but show symbols for an earthquake, a natural disaster.

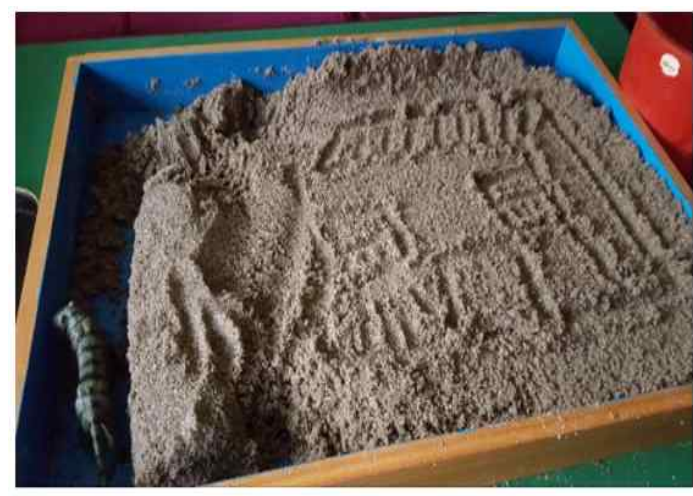

A woman in her 40 s 


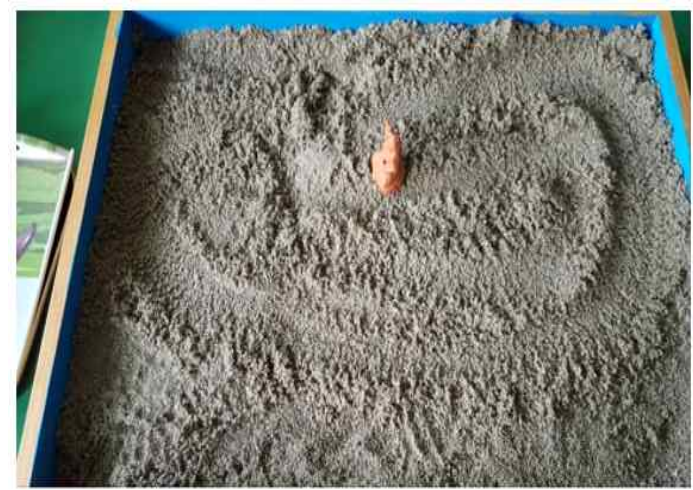

A woman in her 30s

In the sandpictures of a woman in her 30s and a woman in her 40s above, the relationship between earthquakes and the god is described well. In the case of the woman in her 30s, Shiva, the Hindu god of creation, birth and destruction, sits on huge marks on the sand, a symbol of an earthquake that shook the ground and killed thousands of people. She said that the reason for the earthquake, and recovery from it, were all Shiva's will. This is an expression based on Hindu thought. In the sandpicture of a woman in her 40s, the shape of a tiger is also expressed as an earthquake. In Hinduism, the tiger is also a symbol of Shiva. She said that it is unknown then the tiger, on the left, would reappear and shake the ground. The wet sand is in an uneven state as if it was twisted by an earthquake, but instead of a collapsed house, she drew a blueprint for her future life, that is, her life.

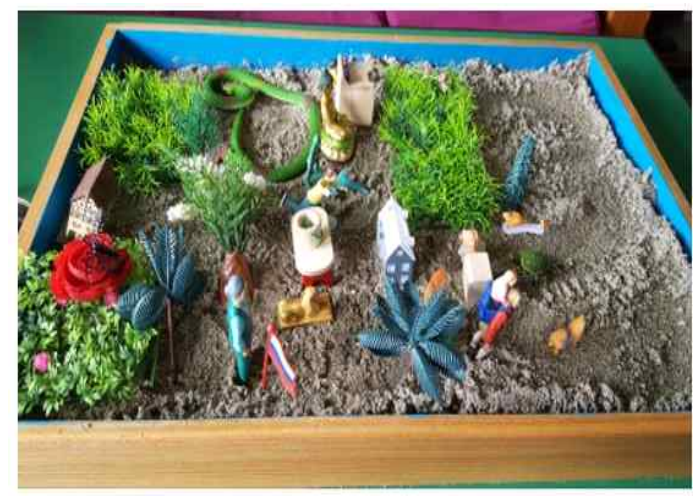

A woman in her 30 s 


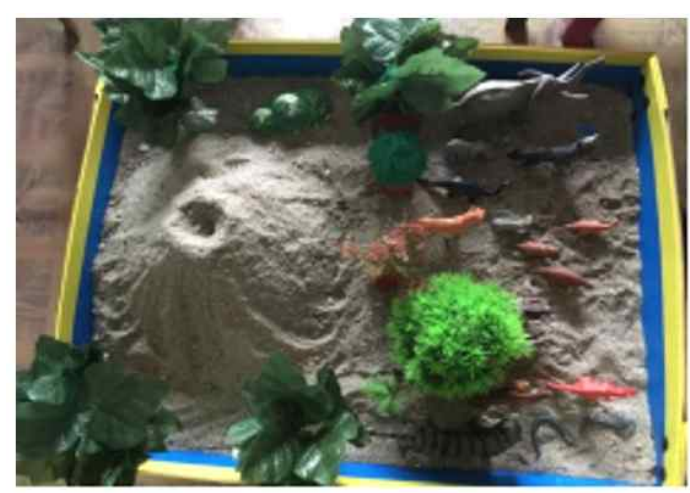

17-year-old boy

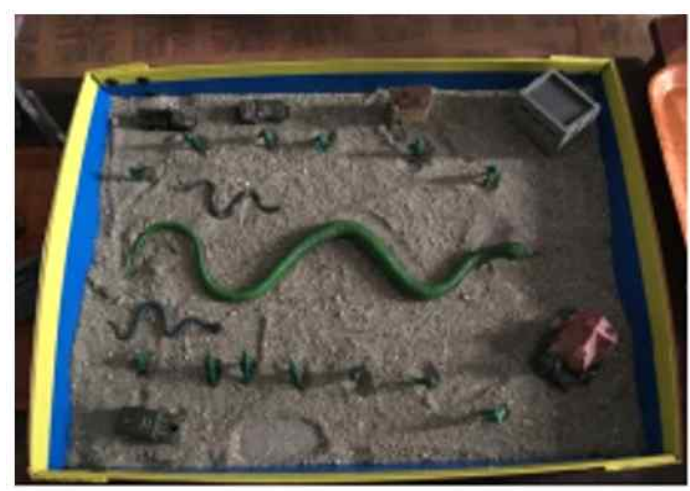

17-year-old boy

One of these two boys, who are different but of the same age, did not use the term earthquake, but said a giant snake appeared and the soldiers were trying to stop it. The building in the right corner is a building split in two, and it symbolizes the traces of the earthquake. It seems to have something to do with survivors' testimony, that they witnessed numerous snakes coming out of the ground just before the earthquake. God is here too. The boy in the first photo also did not use the word earthquake and said that a huge volcanic eruption had occurred and the animals were running away. At that time, the strong earthquake stopped, but the small aftershocks continued, so the fear that a large-scale earthquake might reoccur seems to have been expressed as a volcano where nobody knows when it will erupt. In addition, the situation in which even their livelihood is threatened by leaving their neighborhood, and where they should leave the group tent village within a few months, seems to have 


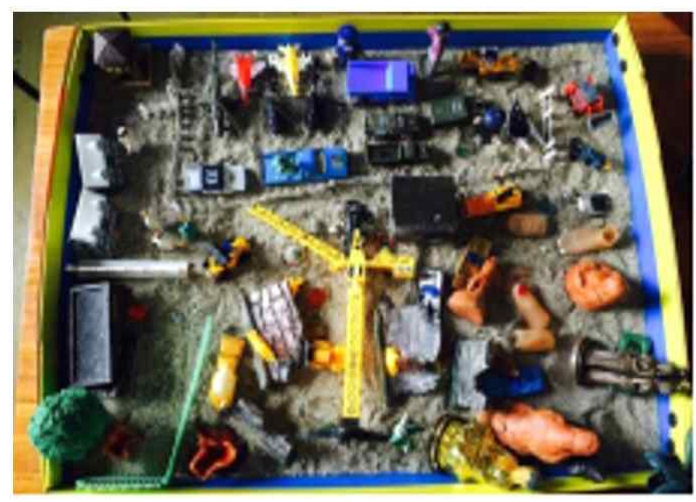

14-year-old male adolescent

aggravated the anxiety of not knowing when it will explode.

This male adolescent's sandpicture looks confusing at first glance. If you look at it closely, however, there are houses that have been destroyed by the earthquake and construction is being carried out to restore them. The arrangement of cars in a row seem to symbolize the restoration of order in the society that was destroyed by the earthquake. Also, there are several Hindu gods in this picture. Nepal is a society dominated by Hinduism and Buddhism, and traditional religious practice remains strong compared to other cultures. The images of gods often appeared in their sandtrays because it is the god who caused the earthquake and a god who makes recovery from the earthquake possible. More importantly, they are playing a game of recovery through sandplay therapy. In the individual aspect, despite the anxiety caused by the earthquake and the instability and discomfort of living in a temporary tent village due to the collapse of the house, attempts to overcome this situation and recover from it are shown as play.

This 30-year-old woman's house was completely destroyed, and she is living without water or toilets in a small tent, not in the group tent village provided by the state. Her husband has used violence against her for a long time and does not support his family. Her dream was to build her own house and live with her children. There are countless small temples in Nepal's cities, towns, and private homes. In addition to going to the temple during certain seasons, they go daily to pray for their bad luck and make wishes to the gods. That house, which remains unfinished in the middle of sand, is such a small temple and yet her own sacred house, where she can live without suffering from violence. In other words, it is not only a physical space, but also peace of mind. It can be said that she performed a sacred ritual on her own during the 


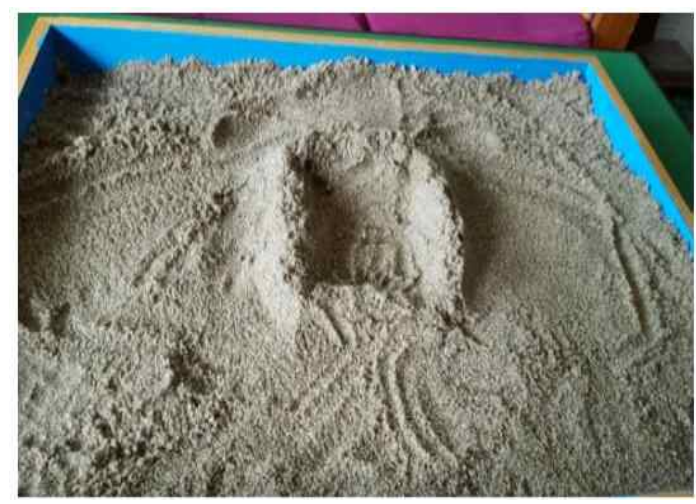

A female victim of domestic violence in her 30s,

sandplay.

These are sand scenes that remind us of how strong humans are despite disasters, trauma, poverty, death of family members/acquaintances, and violence. It is not easy to imagine that such a result would be achieved if such work was carried out only through language counseling. Sandplay therapists have great means through the use of symbols and images.

The symbolic image created by the psyche is not just imagination. It could not be used as a therapeutic approach if it was only imagination. The following is one experimental example to prove this. In 2013, Gregory Berns of Emory University in the United States had 12 university students read a novel every evening, and took a brain scan with fMRI (Functional Magnetic Imaging Device) the next day, and also took a brain scan with fMRI 5 days after novel reading was finished. As a result, it was found that the effect of novel reading persisted even after the experiment was over. The result of the experiment showed that the neural circuit in the left temporal cortex, the part of the brain responsible for language sensitivity, was activated, and more importantly, the central sulcus, the primary sensorimotor area of the brain, was also activated. Berns said that the central sulcus area of the brain is the area where the nerve cells related to the body movement of running are activated even when just thinking about the movement of running. He said that the activation of this brain region when reading a novel means that you feel as if you are the main character of the novel (Yonhap News, December $27,2013)$. When you read a novel with a great main character, you feel as if you become the main character, and it happens biologically as well. Needless to say, a novel is imaginary, but sandplay therapy is an imaginary work performed by hands, so it can be assumed that the 
Journal of Symbols \& Sandplay Therapy, Vol.12 No.2.

effect will be similar. It can be said that working with imagination can actually change our lives, which has been proved neurobiologically.

\section{Conclusion}

We are living in an era when we must put on 'tal', which is our real problem, and show it to 'God' (that is, face our inner self) to please God to make tal pass, rather than covering our face with a mask as we did in the traditional society of the past. In an era when we need to truly see what the mask of the times for each of us and mankind is, sandplay therapists as healers are asked to play Tal Chum Gut Nori (shamanistic mask dance play) or Tal Chum Gut Nol for 'our' clients and ourselves in sandplay. By doing so, we may be able to prevent the archetypal shadows caused by the pandemic from mingling with the negative complex in our shadows and disintegrating the personality or rendering the ego inoperable. Just as those who performed mask dance plays show humility to their god by truly showing what their problems were with true masks, we as healers need to put on our true masks and humble ourselves before nature and the nature of our true self. The dance of the mask dance is not a dance that is performed through great practice, but a dance performed by the mind and body voluntarily. That is, it is a play. Playing and dancing based on imagination are not 'useless' activities that are only imaginary. Imagination expresses our psyche, and as Dr. Berns' experimental results show, imagination affects our real life in the form of changing our minds and emotions. Nevertheless, we experience death in these times, due to corona affecting the people around us. Thus, we must prepare for the death of those around us, and further our own death and life after death by playing what death means in life and what life is like after death. In the era of a pandemic, clients who come to a psychotherapist because they cannot stand their fear and anxiety, feel fear that the world will be destroyed and believe that death is the end of everything. However, Jung said in his autobiography, "A man must be able to prove, even by confessing his own incompetence, that he has done his best to formulate an opinion or to make a statement about his life after death (Jung, 1963/2003, p. 344)." Of course, this would apply to psychological death as well as physical death. Even if we are psychologically afraid of death, we should do our best to think that it is not the end and what it means for us. 
Mikyung Jang / Integration of Psyche and Matter and Sandplay Therapy in the Era of Pandemic (Mask, Tal)

\section{References}

Kim, S-M. (2017). Analytical Psychology and Literature: The Difference of Attitude toward the Art between S. Freud and C. G. Jung. Theology and Praxis, 53, 217-254. doi: http://dx.doi.org/a0.14387/jkspth.2017.53.217

Korea's suicide rate is the highest among OECD countries, 'stigma' $\cdots 266$ per 100,000 population. Daily Economics (January 20, 2020). Retrieved from Retrieved from biz.newdaily.co.kr/site/data/html/2020/06/01/2020060100129.html Accessed at May 302020

Rhi, B-Y. (1986). Some aspects of the healer archetype in Korean shaman's songs of sonnim, gods of smallpox. Shim-SongYon-Gu, 1, 5-27.

Rhi, B-Y. (2012). Korean shamanism and analytical psychology: Searching for sufferings and healing. Seoul: Hangil-sa.

Lee, S-H. \& Jang, M. (2020). The effect of group sandplay therapy on psychological health and resilience of adolescent survivors of Nepal earthquake). Journal of Symbols and Sandplay, 11(2), $45-78$.

Lim, J-H. (1999). Hahoe Masks, Hahoemask playdance. Seoul: Jisik-Sanupsa

Jang, M. (2014). The Archetypal and Psychological Symbolism of Masks in Sandplay Therapy. Journal of Symbols and Sandplay, 5(2), 1-10.

Jang, M. (2017). Analytical Psychological Sandplay Therapy. Seoul: Hakji-sa.

How a book really can change your life: Brain function improves for DAYS after reading a novel (Mail Online 27 Dec. 2013). Retrieved from

https:/www.dailymail.co.uk/sciencetech/article-2529855/How-book-really-change-life-Brain-function-i mproves-DAYS-reading-novel.html Accessed at June 1, 2020.

Kawai, T. (2019). Big stories and small stories in the psychological relief work after the earthquake disaster: life and death. In L. Huskinsons \& M. Stein (ed.), Analytical psychology in a changing world: The search for self, identity and community. London/New York: Routledge.

Jacobi, J. (2013). The psychology of C. G. Jung. New York: Routledge.

Jung, C. G. (1935). Tavistock lectures. CW18, Bollingen Series XX. Princeton, NJ: Princeton University Press.

Jung, C. G. (1933/2017). Modern Man In Search of a Soul. Boston, MA: Mariner Books.

Jung, C. G. (1970). Civilization in transition ( $2^{\text {nd }}$ ed.). Princeton, NJ: Princeton University Press.

Jung, C. G. (1970). Definitions. In C. G. Jung, Psychological types. CW 6, Bollingen Series XX. 
Journal of Symbols \& Sandplay Therapy, Vol.12 No.2.

Princeton, NJ: Princeton University Press.

Jung, C. G. (1981). On the nature of psyche. In C. G. Jung, The structure and dynamics of the psyche $\left(2^{\text {nd }}\right.$ e.). CW8, Bollingen Series XX. Princeton, NJ: Princeton University Press.

Jung, C. G. (1990a). Symbols of transformation ( $2^{\text {nd }}$ ed.). CW5, Bollingent Series XX. Princeton, NJ: Princeton

Jung, C. G. (1990b). Archetype and the collective unconscious $\left(2^{\text {nd }}\right.$ ed.). CW9, Bollingent Series XX. Princeton, NJ: Princeton

Jung, C. G. (1993). Psychologie und Alchemie, Psychology and alchemy, Bollingen Series XII. (Tr. Rascher Verlag). Princeton, NJ: Princeton University Press. (1968).

Jung, C. G. (2003). Dreams, memories and reflections (A. Jaffe, Trans. In 1963 by Rhi). Korea Jung Institute.

Jung, C. G. (2004). Mensch und Kulture (C. G. Jung Translation Committee). Seoul: Sol Publishing Company.

Jung, C. G. (2009). The Red Book: Liber Novus. Tr. M. Kyburz, J. Peck, S. Shamdasani. (ed.). New York: W. W. Norton.

Kalff, D. (1980). Sandplay: A psychotherapeutic approach to the psyche. Cloverdale, CA: Temenos Press.

Leavy, P. (2020). Method meets art: Arts-based research practice ( $3^{\text {rd }}$ ed.). NewYork: GuilfordPress.

Sedgwick, D. (2001). Introduction to Jungian psychotherapy: The therapeutic relationship. New York: Brunner-Routledge.

Stein, M. (2020a). Interview with Murray Stein for Pacifica Graduate Institute. Retrieved from https://www.pacificapost.com/interview-with-murray-stein Accessed at July 8, 2020

Stein, M. (2020b). A World Shadow: COVID 19. Retrieved from

https://chironpublications.com/a-world-shadow-covid-19/

Taborada, F. (2020). Breath and the Asphyxiating Life in Time of the Coronavirus. C. G. Jung Institute of Chicago.

https://jungchicago.org/blog/freddie-taborda-breath-and-the-asphyxiating-life-in-time-of-the-coronavirus/

Wilber, K. (2000). Integral psychology: Consciousness, spirit, psychology, therapy. Boston, MA: Shambhala Publication Inc. 
Mikyung Jang / Integration of Psyche and Matter and Sandplay Therapy in the Era of Pandemic (Mask, Tal)

수정인 : 2021. 11. 27 게재확정일 : 2021. 12. 06 


\title{
팬데믹 (탈, 마스크)의 시대의 정신과 물질의 연결 및 모래놀이치료* \\ Integration of Psyche and Matter and \\ Sandplay Therapy in the Era of Pandemic (Mask, Tal)*
}

\author{
장 미 경**
}

Mikyung Jang

\begin{abstract}
$<$ Abstract $>$
In this paper, the symbolic meaning of the pandemic and the role of the sandplay therapist in integration of psyche and matter were attempted to be understood from an analytical psychology perspective. Traditionally, in Korean culture, when an epidemic spreads, mask dance plays such as Byeolshin Tal Chum Gut Nori which means shamanistic mask dance play and rituals were offered to appease the gods who brought the epidemic, leaving minimal damage and waiting for the god to pass. In that sense, the expression 'byeolshin' refers to both a god and a contagious disease called smallpox. The use of mask, tal in these shamanistic mask dance plays and rituals are related to the meaning of 'mask'. Mask in Korean means mask, but it is also a word that means diseases, problems, breakdowns, shortcomings, difficulties, etc. Also, playing is an interesting part, which means that play has a healing effect and is a way to appease the archetypal fears and anxieties caused by the divine plague. Just as our traditional culture did, in the era of the corona pandemic (mask, mask), sandplay therapists are in a time and situational position to play a role in making clients realize that matter and psyche or spirit, that is, external things are internal projections. This is because sandplay therapy is a play and a ritual, and it is a symbolic and healing approach that allows each person to meet their inner 'god', that is, their true Self. This process must occur first in the therapist, and only the therapist who has experienced such a process can understand the client's process in terms of the archetypal transference-countertransference relationship. Also, it was tried to explain the archetypal fear of the pandemic by linking it with the personal complex, and the symbol of the pandemic that appears in sandplay therapy was presented along with the symbols of earthquake disaster in Nepal.
\end{abstract}

Keywords : Corona, pandemic, mask, tal, play, sandplay therapy, integration of matter and psyche

* 이 논문은 2021년도 남서울대학교 학술연구비에 의해 연구되었음.

** 남서울대학교 아동복지학과 (jangmiky@nsu.ac.kr) 
Journal of Symbols \& Sandplay Therapy, Vol.12 No.2.

\section{I. 서 론}

물질적인 것 또는 외부 대상에 집착 하지 말고 그것을 내면 투사의 상징으로 받아들이고 그것이 내적 정신에 갖는 상징적, 개인적 의미를 찾고자 하는 것이 물질과 정신을 연결하 는 작업이며 모래놀이치료 작업이 목표로 하는 것이다(Steinhartd, 재인용 장미경, 2017; Kalff, 1980). 코로나 팬데믹의 발생 원인은 아직 분명히 규명되지는 않지만 한 가지 분명한 것은 성공, 성취, 부, 명예, 지위, 인정, 만족 등 외부의 것에 지나치게 집중하던 삶의 태도에서 내면의 것을 보라는 신호일 것이다. 그 이유는 인간의 지나친 자연 통제, 더 많은 힘을 얻 고자 하는 시도가 불러온 결과이기 때문이다. 4 차산업혁명 시대라는 급격한 기술문명의 변 화와 팬데믹이라는 바이러스의 대유행은 그 어느 시대 보다 인류의 원초적 불안을 자극하 는 원형적(archetypal) 투사가 일어나는 현상으로 작용하고 있다. '원형적(archetypal)'이라는 표 현을 사용하는 이유는 팬데믹의 의미가 질병으로 인해 생사와 관련되어(절대적인 것) 공포, 두려움, 불안, 불확실감, 통제할 수 없음 그리고 더 나아가 이 시대의 존재의미에 대해 질 문하게 한다는 의미에서이다. 이 상황이 궁극적으로 어떠한 결과로 이어질지는 아무도 알 수 없으나, 그것이 의미하는 것, 그것이 우리에게 요구하는 것은 삶의 태도의 변화, 그 동 안 소홀히 해 온 것에 대한 관심을 기울일 것을 요구하는 신호라는 점은 분명할 것이다. 팬데믹에 대한 이러한 관점은 외적, 물질적 것을 정신내적 관점에서도 보고자 하는 분석심 리학의 이론적 관점을 반영한다(Jacobi, 2013).

팬데믹과 같은 상황에서는 대부분의 사람들이 불안과 두려움을 느끼지만 심리치료자를 찾아오는 내담자들은 더 심각한 상황에 처해있을 수 있다. 특히 코로나 발생 이전부터 심 리적, 관계적 취약성즉 부정적인 개인적 컴플렉스를 갖고 있던 내담자들은 코로나 팬데믹 상황에서 더 부정적 영향을 받을 수 있다. 이러한 상황은 성인내담자 뿐 아니라 아동청소 년 내담자에 대해서도 마찬가지이다. 심리치료자들은 아동, 청소년들이 성인들의 기준, 기 대, 요구에 얼마나 고통 받아왔는지 너무 잘 알고 있다. 스스로 저항할 수 없는 개인들에게 어른들의 욕심에서 기인하는 일방적인 태도와 가치를 강요하여 그들의 내적 세계를 희생시 키고 있다. 그 결과로 우리사회는 전 세계에서 가장 높은 청소년 자살률이라는 타이틀을 갖고 있으며 2017년 대비 2020년 청소년 자살률이 다른 연령대에 비해 가장 높았다(뉴데일 리경제, 2020). 모든 아동청소년이 스스로 그렇게 할 수 있는가의 의문을 갖게도 하지만 다 행스럽게도 BTS현상처럼 자신의 삶에 대한 직관적 성찰능력을 가진 청소년들이 자신들의 삶을 찾으려는 애씀을 청소년들이 하도록 영향력을 기치고 있다. 이러한 시대적 변화는 심 리치료자가 새로운 시대에 직면하여 요구 받는 역할 변화가 무엇인지 생각하게 한다.

본 논문에서는 인간의 정신에서 일어나고 있는 것과 물리적 세계에서 일어나고 있는 코 로나 팬데믹이라는 사건의 관계를 이해하기 위해 분석심리학적 관점에서 팬데믹의 상징적 
의미를 해석하였다. 같은 맥락에서 팬데믹(탈, 마스크) 시대의 모래놀이치료 즉 동시성적 측 면에서 물질과 정신의 연결의 방법으로서의 모래놀이치료 그리고 모래놀이치료자의 역할을 논의하였다. 또한 팬데믹의 원형적 두려움과 개인적 콤플렉스를 연결하여 설명하고자 하였 으며 팬데믹을 재난의 일종으로 보고 모래놀이치료에서 나타나는 팬데믹의 상징을 다른 재 난 상징들과 함께 제시하였다.

\section{1. 팬데믹의 시대는 왜 탈의 시대이며 그것의 상징적 의미는 무엇인가?}

한 마디로 팬데믹은 탈이 났다는 말로 요약 표현될 수 있다. 공포, 멸망, 죽음과 같은 공 포는 절대적이고 근원적이며 신적인 것이기 때문에 원형적이다. 즉 원형적 경험은 신적인 것은 감동, 거룩함, 엑스터시 등과 같은 긍정적인 감정경험도 일으키지만 인간의 힘으로 어 쩔 수 없는 강력하고도 부정적인 영향을 미칠 수 있다. 즉 팬데믹이라는 탈은 우리 시대의 원형적 그림자이다. 개인의 그림자의 상징인 블랙스완 보다 더 거대한 그림자인 것이다 (Stein, 2020a, 2020b). 'mask'는 한국어로 '탈'을 의미한다. 탈은 mask처럼 얼굴을 가린다는 의 미 외에 몇 가지 다른 의미로도 사용되는데 그것은 전염병의 유행, 심신의 질병, 기계나 연 장의 고장, 사람들의 나쁜 버릇이나 결점, 일부러 결점을 찾아내려고 하는 태도인 트집 잡 기, 부정적 사고(accidents), 불평불만, 사회적 문제나 모순 등을 의미한다(임재해, 1999). 예를 들면, '그 사람은 그게 탈이야', '그것이 탈날 것 같다' 등의 표현이 그 예이다. 따라서 탈을 쓰고 춤, 극, 굿, 신에 대한 제의를 수행하는 탈춤굿놀이를 보면 그 사회와 문화 그리고 거 기에 속한 개인들이 어떤 문제를 안고 사는지 알 수 있다. 전통적으로 행해졌던 탈춤굿놀 이인 안동하회별신굿탈놀이 전승에서 '별신' 이라는 것도 수 만 명의 목숨을 앗아갔던 전염 병인, 마마신, 손님, 천연두로 불리는(이부영, 1986) 바이러스에 의한 질병을 의미하며 더 나 아가서는 질병과 마찬가지로 삶에 존재하는 여러 가지 탈을 의미한다.

현대의 사람들에게 천연두는 마치 원시 시대에나 존재했던 질병처럼 들린다. 그만큼 우 리시대는 바이러스, 세균과 같은 자연을 정복했고 통제할 수 있다고 믿어왔다. 그러나 현재 자연을 지배하고 통제할 수 있다고 믿는 인간의 팽창된 자아는 코로나 팬데믹 같은 자연의 ‘복수' 앞에 무력해져 있다. 말 그대로 탈이 난 것이다. 인류의 과학능력이 바이러스쯤은 정 복할 것이라 자만했던 인류에게 보이지 않을 정도로 작은 바이러스는 과학을 종교 위에 두 고 과학으로 종교를 증명하려 들었던 인류의 자부심에 도전하고 있는 것이다(Wilber, 2020).

분석심리학적 관점에서의 문제는 개인이 자신의 내적 삶과의 단절이다. 온전한 자신의 삶을 살아가라는 '내면 즉 각자의 '자연 (본성)'의 부르심'에 귀를 막는 것이다. 물질 자연과 우리 내면의 자연을 숨쉴 틈을 찾을 수 없게 막아버린 것에 대해 자연은 기도폐쇄를 만들 어 ‘복수’하는 것인지도 모른다. 혹자는 코로나가 생화학연구실에서 일부러 퍼뜨린 것, 실수 
Journal of Symbols \& Sandplay Therapy, Vol.12 No.2.

로 유출된 것, 음모론, 또는 야생동물을 식용으로 사용한 것 등에서 기인한다고들 한다. 그 러나 어떤 연유에서 시작되었든 그것은 인간이 자연을 함부로 사용하고 자연의 힘을 통 제할 수 있다고 믿은 오만에서 기인한 자연의 복수라고 할 수 있다. 즉 개인의 그림자인 black swan을 넘어선 우리 시대의 원형적 그림자인 것이다. 눈에 보이지 않을 정도로 작은 것이 인간을 어쩌지 못할 것이라 여기는 것처럼 인간은 보이지 않는 내면 자연의 세미한 음성을 경시한다. 같은 맥락에서 Freddie Taborda는 코로나 바이러스가 일으키는 가장 심 각한 증상인 호흡곤란, 혈액의 산소수준 급감이 심리적 상징성을 갖고 있다고 언급했다 (Taborada, 2020). 우리의 삶의 방식이 이런 기도폐쇄적(asphyxiating)이라는 것이다. 집단무의 식의 관점에서 볼 때, 우리는 숨막히게 하는 삶의 태도를 갖고 있다: 공부를 잘 해야 한다 거나, 성공해야 한다거나, 더 많은 재산을 가져야 한다거나, 유능해야 한다거나, 열등해서는 안 된다거나, 오로지 일등 하는 자만이 가치 있는 사람이라거나, 좋은 사람으로 보여야 한 다거나, 완벽한 부모여야 한다거나, 넓은 인간관계를 가져야 한다거나, 사랑 받는 존재여야 한다거나 등등. 어떤 사람들은 그러지 못한 자신의 삶 때문에 밤마다 더 잘 하자고 자신을 다그치거나 죄책감에 시달리거나 자신이나 자식에게 안 좋은 일이 일어날지도 모른다는 불 안으로 괴로워 잠 못 들어 한다. 더 나아가서는 삶의 방향감을 잃고 두려워한다. 얼마나 숨 막히는 '기도 폐쇄적' 삶인가? 어떤 사람들은 이런 불안과 고민으로부터 벗어나는 방어기제 로서 코로나는 꾸며낸 음모일 뿐이라고 일축하기도 한다. Murray Stein은 이런 사람들에 대 해, 자기를 보기 두려워하고 온갖 미디어를 통해 바깥 세상을 보고자 하는 팬데믹 시대의 사람들이라고 기술했다(Stein, 2020a).

또한 코로나는 원형적인 신의 그림자(Umbra Mundi)이며 원형적 신의 그림자는 전율, mysterious fear를 일으키며, 보이지 않는 코로나에의 대처는 보이지 않는 내면 세계를 보는 것으로 밖에는 극복할 수 있는 방법이 없다고 언급했다. In Jungian work we encourage our clients to work with their symbolic images in a similar way - to attend to them, to speak with them, to listen to them(Stein, 2020b). 이것이 자신의 내면과 연결되는 상징적 작업방법이다. 이러한 작업방법에는 Jung이 처음 사용한 적극적 상상(active imagination)을 비롯하여 다양한 방식의 명상, 기도, 모래놀이치료, 꿈분석 작업과 같은 것들이 있다.

우리 조상들은 지혜로워서 탈이 났을 때 또는 탈이 날 것 같을 때 어떻게 해야 하는지 알고 있었다. 탈이 났을 때는 신(내면)을 기쁘게 하고 위로해서 최소한의 피해로 탈이 지나 가도록 마음을 다하여 춤을 추고 놀았으며 신께 제의를 올렸다. 그들은 전염병이 신에 의 한 것이라고 생각했다. 그래서 그 이름이 별신굿탈춤놀이 이다. 그들은 탈을 쓰고 놀이와 신에 대한 제의(ritual)라는 의식을 실행하면서 원초적 불안과 공포를 일으키는 원형적인 신 의 그림자를 달랬을 뿐 아니라 탈놀이와 의식을 통해 동료인간과의 연대의식, 집단 자아적 대처를 통해 죽음의 공포와 불안에 대응했다. 그것이 Jung이 그의 환자들과 예술적 상징 작 
업을 하고 Jung 자신의 환상작업을 Red Book(Jung, 2009)에 기술한 이유이다.

(원형적) 탈이 났을 때 개인의 심리적 콤플렉스(의식에 통합되지 못하고 ‘죽었던' 부분)가 활성화 되어 증상을 악화시키는 경향이 있다(이부영, 2012). 팬데믹이나 지진과 같은 재난 등 원형적 사건이 미치는 영향 즉 원형이 개인에게 창조적 작용과 파괴적 작용 중 어떤 것 을 할 것인지는 자아(ego)가 얼마나 무의식의 내용을 통합할 수 있는 능력을 가졌는가에 따 라 그리고 무의식에 얼마만큼 강한 감정적 콤플렉스(개인적 콤플렉스)들이 억압되어 표출될 준비를 갖추고 있는가에 따라 결정된다(이부영, 2012, p. 369).

위에서도 언급한 바와 같이, 전통적인 탈춤굿놀이처럼 놀이, 꿈, 예술, 꿈, 굿, 기도와 같 은 일종의 예술적 의례(artistic ritual)는 자아의 한계가 무너지지 않도록 하는 측면에서의 기 능도 갖고 있다. 모래놀이치료는 이와 같은 기능을 해왔으며 앞으로도 그러한 기능을 강화 해야 한다. 이에 대해서는 뒷부분에서 구체적으로 설명되어 있다.

이부영에 의하면, 천연두신과 죽은 자의 영혼은 다른 것이다. 천연두신은 집단무의식의 원형과 깊은 관계가 있으며 죽은 자의 영혼은 개인무의식 또는 개인적 콤플렉스와 관련된 다. 이부영(2012, p. 208)은 한국의 제주도에서 천연두신인 삼승할망이 천연두를 일으키며 천연두를 않는 아동의 허튼 소리가 신의 소리이며 얼굴의 반흔은 신의 발자국이라고 사람 들이 생각했던 점으로 볼 때 천연두는 일정 기간 신체 내를 통과하는 것을 의미한다고 하 였다. 이는 코로나 바이러스가 일정 기간 신체를 통과하는 것과 같다. 이것은 죽은 자의 영 혼(개인적 콤플렉스)이 산 자의 신체(의식)에 들어가 문제를 일으키는 것과는 다르다. 천연 두신인 삼승할망은 원형인 대모(Great Mother)로서 일종의 의신이며 병도 주고 고치기도 하 는 양면성을 갖고 있다. 죽은 자의 영혼은 제대로 자신의 운명대로 삶을 살지 못하고 죽은 자들의 혼이기 때문에 즉 인간 정신의 살아내지(lived out) 못한 부분, 제대로 의식으로 통합 되어 인격으로 형성되지 못하고 억압된 부분들이기 때문에 이 부분을 위로하고 통합해야 하는 것이다. 그렇지 않으면 살아있는 인간들에게 해를 끼치기 때문이다. 다시 말하면, 죽 은 자의 영혼이 그 합당한 곳으로 가지 못하고 살아있는 자들 틈에 남아 있다는 것은 의식 화 해서 통합하지 못한 강한 감정이 있다는 뜻이다(이부영, 2012, p. 431). 산 자를 괴롭히는 죽은 자의 영혼에 대한 이야기가 전 세계에 많고 그 노여움을 풀기 위해 제사나 굿이 끊임 없이 계속된다는 것이 이를 증명한다. 죽은 자들에 대한 여러 가지 제의와 금기는 결국 못 다한 삶을 완성(wholeness)시키는데 목적이 있다(이부영, 2012, p. 431). 해결되지 않은 개인적 콤플렉스가 강력하게 개인에게 작용하고 있으면 팬데믹과 같이 원형적 공포를 일으키는 상 황은 강한 콤플렉스에 끌려 다니는 취약한 자아를 더욱 약하게 만든다. 그러므로 집단무의 식적 콤플렉스로부터 개인적 콤플렉스를 분리하고 의식에 통합하는 것이 필요하다. 
Journal of Symbols \& Sandplay Therapy, Vol.12 No.2.

2. 팬데믹(탈, 마스크) 시대의 모래놀이치료: 물질과 정신의 연결

그렇다면 펜데믹과 같은 원형적 현상의 시기에 심리치료자인 모래놀이치료자의 역할은 무엇인가에 대한 논의가 필요하다. 무엇을 해야 하는 것인가 또는 무엇을 하지 말아야 하 는 것인가와 관련 있다. 심리치료자 자신도 어쩌면 탈(마스크)로 진짜 페르조나인 얼굴을 가려야 한다. 즉 탈이 있다는 것을 얼굴에 쓰는 것으로 자신의 진정한 페르조나를 겸허하 게 보이면서 놀이를 하는 것으로 신을 기쁘게 하여 탈이 지나가게 해야 하는 시대에 살 고 있다.

모래놀이치료는 인간의 정신, '영혼'을 물질과 연결시켜 자신의 내면과 하나 되게 하는 심리치료 접근이다 (많은 모래놀이치료자들이 내면을 외부세계에 맞추려 시도하긴 하지만). 두려움, 불안 등에 대한 부인 없이 홀로 있음, 침묵, 내향화를 하는 것이 이를 위한 방법이 다. 내담자들은 대부분 이것을 혼자 하지 못하기 때문에 스스로 할 수 있을 때까지 심리치 료를 받는다. 그렇게 못하는 이유는 지금까지 살아온 방식으로 인해 그렇게 하는 것이 대 부분의 사람들에게 힘든 경험이기 때문이다. 이제는 어쩔 수 없이 그렇게 해야 하는 시대 상황에 몰려 있다. 그것이 팬데믹이 갖는 심리적 의미일 것이다(Taborda, 2020). 사람들은 어 쩔 수 없이 과거보다 집에 더 머물면서 산책, 책 읽기, 가족들과 시간 보내기, 요리 하기 등 코로나 이전에는 그 비중이 적었던 일들을 하고 있다고 말한다. 홀로 있음(solitude)은 마 음 속에 떠오르는 이미지, 감정, 생각 등을 통해 각자의 자기(Self)와 연결될 수 있는 기회를 준다. 따라서 통찰(개성화)을 위해 마음 속에 떠오르는 것들과 친해질 필요가 있다. 침묵은 마음의 번거로운 안달과 스트레스로부터 진정될 수 있게 한다(Steinhardt, 장미경 2017 재인 용). 이 모든 내향화(introversioning)의 방향은 개인 내면에 있는 진정한 자기 자신과 연결되 는 에너지 흐름의 방향이다. 이것은 강조할 필요도 없이 내담자들에게 모래놀이치료 작업 이 필요한 이유를 설명해준다. 치료실에서뿐 아니라 궁극적으로는 치료자 자신과 내담자가 혼자, 스스로 할 수 있어야 함을 의미 한다. 이미 언급한 바와 같이, 이러한 작업은 치료자 내면에서부터 시작되어야 한다. 타인의 상처를 치유하기 위해서는 치료자 자신부터 내면과 연결하는 노력 필요. 상처 입은 치유자가 아니라 상처입고 치유 받은 치유자로서의 치료자 가 필요하다(Jung, 1935; Sedgwick, 2001).

신을 달래어 질병이 지나가도록 하기 위한 방법이 탈춤놀이였다는 점이 흥미롭다. 탈춤 놀이에서 놀이는 놀음과 같은 뜻으로 그 의미는 여러 사람이 모여서 즐겁게 노는 일 또는 그런 활동을 의미하며 굿, 풍물, 인형극 따위의 우리나라 전통적인 연회를 통틀어 이르는 말이기도 하다(국립국어원 표준국어대사전). 이 뜻을 보면 놀이가 예술적이라는 것을 알 수 있다. 따라서 우리의 탈춤놀이라는 것은 인간의 예술적 활동에 포함된다. 모래놀이치료를 표현예술치료에 포함시키기도 하고 그렇지 않기도 한다. 그러나 표현예술치료라는 표현이 
특정 예술치료를 지칭하는 말로 사용 되어 왔기 때문에 오해를 피하기 위해 넓은 의미의 예술이라는 측면에서 '창조적' 예술치료에 포함시키는 것이 더 적합할 것이다. 창조적 예술 치료는 의미창조(creating meaning), 임파워머트, 정체성, 감정표현, 다중감각적 의사소통, 관계 형성, 상호주관성(intersubjectivity) 등에 초점을 맞추는 치료접근이다(Leavy, 2015). 넓은 의미의 예술을 통해 자기를 실현(individuation, wholeness)하려는 원형적 충동이 누구에게나 존재하기 때문에 전문 예술가의 전유물로서의 예술이 아닌 넓은 의미의 예술로 이해되어야 한다. 또 한 포토샵이나 디지털 이미징기법이 예술표현 장르에 포함된다면 모래놀이치료가 예술적 심리치료 접근에 포함되지 않을 이유가 없다. Jung은 예술에 대해 각자 내면에는 예술가 원 형이 있어서 단순히 미술, 음악 등의 예술뿐 아니라 넓은 의미의 진정한 예술은 영혼에서 나오는 것으로서 한 쪽 방향으로 삶에 쫓기거나 삶의 에너지가 없어지거나 시대적 위기나 상황적 위기에 처했을 때 또 다른 방식의 삶의 이미지상징들을 보여주기 때문에 내면에 대 한 예술작업이 필요하다고 했고 위에서 언급한 바와 같이 자신도 그렇게 했다(Jung, 2009).

예술가들에게 작품을 창작하는 것의 의미에 대해 Jung은 예술작업이 환타지(환상 즉 이 미지 상징)을 통해서 주어지는 근원체험이라고 했다. 환상은 아름다운 환상만 있는 것이 아 니라 의식을 딿고 나온 환상 중에는 사람들을 낮설고 어두운 혼돈 속으로 데려가면서 그 개인을 충격에 빠뜨리는 환타지도 있다. 그러나 두렵고 혼돈스러운 것이라도 그것을 진지 하게 받아들인다면 그것은 창조에 임하는 사람들을 또 다른 세계로 안내한다. Jung은 원형 이미지 경험을 근원체험(primordial experience)으로 설명했으며 근원체험은 시간과 공간 그리 고 문화를 넘어서는, 인간 이전의 시간들의 깊은 곳에서 또는 인간을 넘어서는 자연으로부 터 나오는 것 같고, 인간이 본성이 취약하고 그것의 작용에 대해 전혀 알지 못한다면 그 힘에 압도당할 위험이 있는 (Jung, 1966/2004, p.161) 체험이지만 이 체험을 용기 있게 다룬 다면 무의식에서 올라오는 에너지는 우리의 인격을 확장, 성숙시키고 진정한 삶과 생명을 유지시켜 준다고 했다(Jung, 1933/1955). 예술을 치유의 방법으로 사용한 이유도 여기에 있 다. 진정한 예술은 우리의 의지와 자아에서 의지적으로 나오는 것이 아니라 무의식에서 생 겨나기 때문이다. 자아 의식성이 너무 강하면 자아의 의지를 따르고자 할 뿐 무의식으로부 터 오는 메시지를 의식하지 못하거나 의미 없는 상상쯤으로 무시해버린다. 무의식에서 오 는 상징이미지에 경청에 해야 하는 이유는 Jung이 언급한대로 의식과 관계없이 자신의 의 지를 가지고 자율적으로 존재하는 인간 심혼의 또 다른 층의 존재가 있기 때문이다. 이것 을 Jung은 심혼 또는 영혼의 작용이라고 명명했다(Jung, 1933/2017). Jung에 의하면 예술작품 의 근원은 영혼인데, 영혼은 인간의 예술 및 학문을 포함한 모든 활동의 모체이고, 근원이 다(Jung, C. G. 융저작번역위원회 역, 1966/2004, p. 156). Jung은 영혼은 신체와 함께 인간의 생명을 구성하는 하나의 실체(substance)로서, 사람들이 세상을 살면서 경험하는 물리적 과정 을 일련의 이미지들로 나타내는 정신의 층이라고 했다. 팬데믹이나 자연재난 같은 원형적 
Journal of Symbols \& Sandplay Therapy, Vol.12 No.2.

사건은 집단무의식 층의 것을 투사하는 상징적 사건이 되며 집단무의식의 투사는 절대적 감동을 느끼게 할 때도 있지만 기존에 잠들어 있던 개인 콤플렉스를 활성화시켜 공포와 불 안, 두려움에 빠지게 한다.

이것은 모래놀이치료 작업의 원리와 동일하다. 자아의지를 잠시 잠잠케 하고 손과 이미 지를 통해 말하는 무의식의 메시지를 듣기 위해 우리는 침묵이라는 방법을 심리치료를 위 해 사용한다. 침묵이란 자아의지나 집착을 내려놓으라는 의미이다. 이런 '예술작업'을 통해 무의식의 메시지를 듣는 것은 우리 내면의 근본 존재와 교감하게 만들고 이 교감은 우리의 삶을 근본적으로 변화시킨다. 이러한 이론적 맥락은 모래놀이치료를 포함하는 예술적 접근 이 왜 탈(마스크)의 시대에 물질과 인간의 정신을 연결, 치유하는 기능을 한다는 것을 뒷받 침한다. Archive for Research in Archetypal Symbolism(ARAS)는 Art and Psyche와 함께 Art in a Time of Global Crisis: Interconnection and Companionship 라는 제목의 글에서 팬데믹 위기 시대 에 상호연결과 인류의 동료애를 위해 예술작업의 필요성을 설명했다. 그러면서 지리적 거 리, 문화, 삶의 양식의 차이에도 불구하고 글로벌 위기의 시대에 동료애, 회복탄력, 위험, 두려움에도 불구하고 희망을 갖기 위해 예술적 이미지작업을 해야 함을 강조한다. 이 단체 들도 격리, 거리두기의 시대에 물질적 연결이 필요하다는 것을 역설하고 있다

사람들은 상상이나 환타지가 실체가 없는 것이고 쓸데 없는 것이라 여기는 경향이 있다. 그러나 Jung은 실체가 없는 것이 아니라 본래 절반은 신체적인 것이고 나머지 절반은 정 신적인 “미묘한 몸체(subtle body)"로 라고 언급했다(something corporeal, a "subtle body", semi-spiritual in nature (Jung, 1955/2004, p. 277). 그 이유는 무의식이 의식에 소통하는 방식은 우리가 일상에서 사용하는 언어와 논리가 아니기 때문이다. 무의식은 상상(환상, 환타지)를 사용해서 소통한다. 상징이미지 방식으로 활성화된 무의식의 메시지는 반드시 바깥 세계(그 것이 사람이든 물건이든 상황이든)에 투사된다. 그러므로 상상은 생명이 있는 육체적인 힘 과 동시 영혼적(원형적)인 힘에서 나온 진한 추출물이다. 참된 상상(vera imagination)은 무의 식의 것을 의식에 알리는 힘을 갖고 있다(This illusion might be well be the vera imaginatio possessed of "informing" power(Jung, 1953/1993, p. 252). Jung은 상상의 힘에 의지하여 환자를 치료하는 방법을 만들었는데 적극적 상상(active imagination)이 그것이다. 그는 환자들에게 꿈 의 이미지나 연상을 자유로운 상상활동으로 확장하거나 개발하는 과제를 주었다. 이것은 개인의 소질이나 재능에 따라 다양한 방법으로 이루어졌다. 이 작업을 반복하면서 Jung은 그의 환자들의 상상 활동에서 특정한 주제와 형태적 요소들을 발견하였고 이것은 많은 사 람들에게서 반복적으로 나타난다는 것을 알게 되었다. 카오스, 이원성, 밝음과 어둠, 위 아래, 좌우 대극, 대극(oppositions)을 초월하는 제 3 의 것, 사각과 십자모양 같은 사위성 (quarternity), 구체나 원, 에너지가 중심으로 집중되는 중심화(centering/centroversioning), 방사선 모양의 배열(constellation) 등을 발견한 것이다. 궁극에는 자기(Self)를 상징하는 만다라를 연상 
시킨다. 이와 유사한 구체적인 형태의 예는 헤아릴 수 없을 정도로 많이 존재하며 모래놀 이치료 장면에서 흔하게 발견된다. 이 작업과 그의 다른 방법의 작업을 통해 Jung은 보편적 인 인간의 행동을 가져오는 그리고 그것을 상상의 형태를 통해 드러내는 어떤 기본 구조원형-가 있음을 제시했다(Jung, 1956/1990b).

팬데믹 뿐 아니라 지진과 같은 자연재난도 분석심리학(analytical psychology)적 관점에서 볼 때 종교 또는 신의 이미지를 떠올리게 만들고 원초적 불안, 공포를 갖게 하는 원형적 현상 이다. 위기 시에 신의 이미지가 떠오르거나 관심을 갖게 되는 것은 정신의 균형을 유지하 려는 특히 집단무의식(collective unconscious)의 자기원형(Self archetype)의 기능의 배열이다(Jung, 1981). 자연재난 그리고 그로 인해 배열되는 자기원형 에너지는 신으로 경험되며 역설적으 로 이 원형 에너지에 자아기능이 범람 당하는 것을 막기 위해서라도 인간은 신의 이미지를 필요로 한다. 원형은 인간영혼의 원초적이고 구조적인 요소이다(Jung, 1970). Jung에 따르면, "원형은 $\cdots$ 그 자신을 의식화될 수 있는 그 밖의 모든 것 즉 관념(ideas)과 이미지로 드러낸 다(Archetype...present themselves as ideas and images, like everything else that becomes a content of consciousness(Jung, 1981, p. 227).” 예를 들면, 초월적 인격으로서 사자, 용, 노현자, 어린이(영 웅어린이 포함), 어머니(원초적 어머니(Primordial Mother)와 대지 어머니(Earth Mother)와 처녀 등으로 상징화될 수 있다(Jung, 1956/1990b). 특히 원형 중 중심원형에 해당하는 자기(Self) 원 형은 신화, 동화, 꿈 그리고 환타지적 이미지를 피겨에 투사하는 모래놀이에서 자연, 사각 이나 원모양 같은 특정한 형태, 보석 같은 귀중한 물건, 치유명약, 왕, 영웅, 예언자, 구세주, 신 등으로 상징화되는 경향이 있다(Jung, 1971, p. 460). 이 자기에 대한 경험은 종교적 계시 의 신성성을 갖고 있다. 따라서 Jung은 경험적이고 심리적인 실재로서의 자기와 신에 대한 전통적 개념 사이에 본직적 차이가 없다고 언급하였다(Jung, 1971). 자기 원형(Self archetype) 은 각자가 고유한, 진정한 개인이 되도록 하는 즉 인격의 전체성을 이루게 작용하는 원형 이며 조절 중심이고 자아를 초월하는 초월적 힘이다(Jung, 1970). 자기 에너지가 자아와 연 결되면 내적, 심리적, 대극적 갈등이 통합된다. 그런데 모든 원형 패턴은 양극성을 갖고 있 다. 즉 한 극은 긍정적이고 생명증진적이며 다른 측면은 부정적이고 삶을 파괴한다(Jung, 1956/1990b). 다른 말로 하면, 창조하고 발달시키고 돌보는 측면과 파괴하는 측면 두 가지를 모두를 갖고 있다. 그것은 자기원형의 상징이미지 중 하나인 시바신이 파괴와 창조라는 두 가지의 측면을 갖고 있는 것과 유사하다.

Jung은 무의식의 예기치 못한 위험한 범람으로부터 자신을 방어하려는 오직 하나의 목적 으로 실시되는 의례가 수없이 많다고 하였다(Jung, 1964). 신적인 것, 신의 분노로 간주되는 자연재난으로부터 인간을 지키기 위해 신을 달래기 위해 만들어진 종교적 의례들을 말하는 것이다(이부영, 2012). 또한 인간은 종교적 의례를 행할 수 있는 종교적 건축물을 만들어 왔 다. 앞 서 언급한 바와 같이, 한국 문화에서도 자연재난이나 전염병이 발생했거나 발생할 
Journal of Symbols \& Sandplay Therapy, Vol.12 No.2.

것 같은 징조가 보일 때 신을 달래는 ritual을 행했다(장미경, 2015). 바다와 관련된 자연재난 이 빈번했던 일본인들은 해변에 신사를 지었고(Kawai, 2015), 네팔은 바다가 없는 내륙국이 기 때문에 해안이 아닌 자연뿐 아니라 마을과 개인의 집안에 작은 사원을 만들었고 종교와 관련된 수많은 태양절기가 존재한다(https://ko.wikipedia.org/wiki/네팔). 따라서 이들의 삶은 신 과 분리될 수 없는 것이다. 바다는 없지만 세상 최고의 높은 봉우리들이 모여있는 히말라 야 산맥이 있고 히말라야 산맥 자체의 거대함 또는 히말라야 산맥과 연관된 거대한 자연의 힘을 경험하였다. 이것은 자연 자체 또는 자연에는 신이 존재한다는 인식을 갖게 한 것으 로 보인다(장미경, 2015). 지진과 그로 인한 인명과 삶의 터전의 상실을 경험하거나 목격한 사람들은 여러 가지 상징적 방법으로 신의 이미지를 활용함으로써 아마도 개인적으로도 그 러한 마술적 의례를 행한다고 가정할 수 있다. 신과 신전은 분석심리학적 심리치료에서는 자기(Self)에 비유될 수 있으며 인간이 자연의 위대함과 순리에 따라야 인간문명을 지켜낼 수 있듯이 내면의 자기(Self)의 메시지를 따르는 것이 자아의 붕괴를 막는 길이다. 그렇지 않 으면 자연, 신 또는 내면으로부터 '보복’을 당한다.

소위 가장 '문명화된 선진국가들'에서는 위에서 언급한 종교와 의례, 이니시에이션 의례 의 기능이 대부분이 소멸되었거나 그 가치가 평가절하되고 있기 때문에 개인 각자가 그런 의례를 수행해야 하는 시대이다. 모래놀이치료가 방향감을 잃고 두려워하는 개인들에게 그 런 기능을 해야 할 것이다. 즉 전염병의 시대에 우리 조상들이 탈춤굿놀이를 한 것처럼 모 래상자 위에서 놀이를 해야 한다.

3. 모래장면에서의 팬데믹 상징: 팬데믹의 원형적 두려움과 개인적 콤플렉스는 모래상자에 어 떻게 상징화 되는가?

강력한 지진으로 수천 명이 사망한 지진발생 직후의 모래놀이치료에서 네팔의 내담자들 은 지진이라는 자연재난과 삶의 파괴, 미래에 대한 두려움 등을 지진 그 자체, 화산폭발, 외계인의 침입, 거대 뱀이나 공룡과 같은 원초적 동물의 공격, 전염병이나 침입, 공격 등으 로 망가지거나 전멸한 세계, 전쟁이 일어나 모든 사람이 죽거나 병이 돌아 모든 사람들이 죽거나 동물이나 괴물이 침범해 모든 사람들이 죽는 장면 등으로 묘사했다(이세화 \& 장미 경, 2020). 모래놀이치료자는 이러한 장면을 어떻게 이해해야 할 것인가? 이런 장면들은 내 면의 재난을 표현하는 무의식의 방법이기도 하다. 모래놀이치료 작업의 원리를 충실히 따 르는 것이다. 코로나 피겨를 직접 사용하거나 코로나라고 언급한 경우만을 코로나와 연결 시키는 것이 아니라 네팔 지진연구가 보여주는 바와 같이 더 넓게 상징화된 것들에 주목할 필요가 있다. 흥미롭게도, Kawai의 모래놀이치료 연구에서도 동일본 대지진을 있는 그대로 묘사하거나 언급한 경우가 더 재난으로 인한 심리적 외상을 극복하는데 어려움이 있었다고 
보고했다(Kawai, 2019).

내담자의 심혼(psyche)이 선택한 피겨나 모래장면이 내담자의 개인적 콤플렉스와 어떻게 관련 있는지, 개인적 콤플렉스가 코로나로 인해 발생한 것처럼 보이는 불안과 어떻게 연결 되는지를 보게 하는 작업이 필요하다. 더 나아가 외부사건에 자아가 동요하지 않기 위해 내면에 더 큰 존재, 본질적 존재가 있음을 깨닫고 그것의 메시지에 따르게 하는 법을 나누 어야 한다. 그것이 물질과 내면세계를 연결하는 방법이다. 더 나아가 정신 외적인 것들에 마음의 평화를 빼앗기고 불안해하며 바깥에 있는 것들(성공, 성취, 획득, 기타 등등)이 우리 에게 평화를 가져다 줄 것이라 믿고 그것들을 얻기 위해 고군분투 하다가 팬데믹이라는 절 대적 불안에 콤플렉스의 힘이 부정적으로 더 강력해져 결국 치료자에게까지 온 내담자들이 바깥 세계의 것이 그 개인에게 무엇을 의미하지를 알게 해야 한다는 의미이다. 자아의 힘 만으로는 내면의 본질적 존재를 바꿔놓지 못한다. 우리는 우리의 자연, 본성 에 순응할 뿐. 우리는 지진도 막지 못하며 눈에 보이지 않을 만큼 작은 바이러스가 변이하면서 수백만의 생명을 앗아가는 것을 막지 못한다. 우리 조상들처럼 우리는 놀이라는 의례로 그것을 달래 면서 그것이 가능한 조용히 지나가기를 바랄 뿐이다.

\section{4. 모래놀이치료에 나타난 재난 상징들}

\section{1) 코로나 상징}

다음의 모래사진은 인간의 힘으로 감당하기 어려운 팬데믹이라는 원형적 사건의 영향을 자아에게 도적인 것으로 만드는 외상을 경험한 아동의 과 연결되었을 때 팬데믹의 영향이 더욱 강력해지는을 보여주는 사례이다.

내담자는 7세의 여자아동으로서, 코로나 발생 초기 시기에 하원 하는 유치원 버스에서 내려 집안으로 들어가기 전 매우 짧은 시간에 젊은 남자에 의해 성추행을 당했다. 이후 부 모로부터 왜 못하게 하지 않았느냐, 왜 소리를 지르지 않았느냐, 왜 부모에게 바로 애기하 지 않았느냐 등의 비난을 받았다. 이 아동에게 바깥 세계는 코로나와 더불어 성추행범이라 는 이해할 수 없는 사람들이 존재하는 매우 두려운 세계가 되었다. 그 이후 좀비가 따라다 니는 것 같은 두려움을 느꼈고 이는 모래상자 장면에도 잘 표현되어 있다. 이 아동의 모래 사진에서 가장 인상적인 것은 상어가 못들어오도록 하기 위해 쌓은 철옹성 같은 벽이다. 벽이 강력해 보인다는 것은 그만큼 불안의 강도가 크다는 것을 의미할 수 있다. 물론 강한 벽을 쌓을 수 있는 잠재적 힘을 의미하기도 한다. 벽 넘어 바다에서는 언제 넘어올지 모르 는 무서운 상어가 있기 때문에 벽을 튼튼히 쌓는 것에 전념하였다. 모래로 벽을 쌓는 것만 으로는 안심이 되지 않았는지 울타리로 버팀목까지 만들었다. 아동은 상어가 좇아오지 못 하게 여러 곳으로 피해 다녔고 그래도 좇아와 이렇게 벽을 만들었다고 했다. 이 사례에서 
Journal of Symbols \& Sandplay Therapy, Vol.12 No.2.
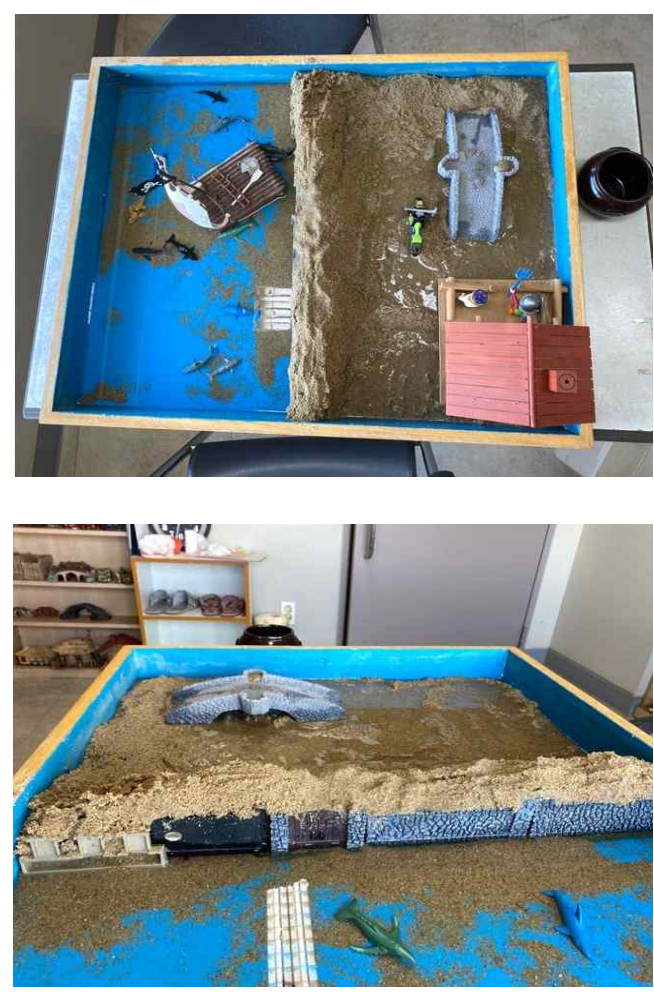

7세 여자아동

상어는 코로나 팬데믹이라는 사건이 개인에게 미치는 원형적 힘을 상징한다. 바다 오른 쪽 세계에는 일상의 삶이 있다. 일상을 상징하는 것 중 하나인 집도 튼튼한 울타리가 쳐져 있 다. 이후 세션이 진행되면서 상어는 코로나로 바뀌었다. 사람들이 코로나를 피해 도망 다닌 다는 이야기로 변화 되었다. 이 사례 역시 코로나 팬데믹과 일상의 다른 트라우마 또는 부

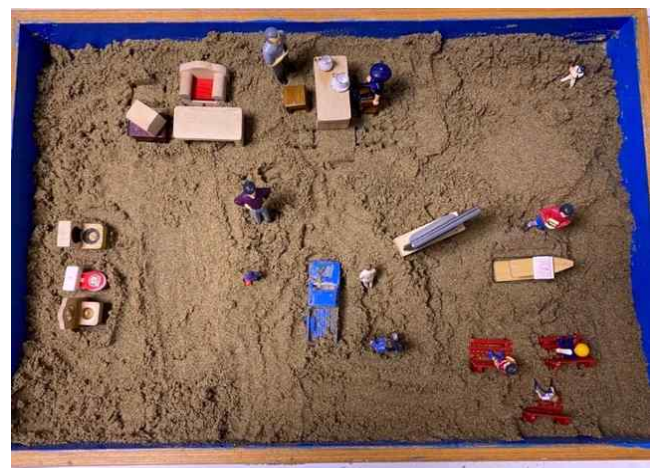

4학년 여자아동 
정적 콤플렉스의 중복은 팬데믹의 영향을 더욱 부정적인 것으로 만든다.

이 사진은 초등학교 4학년 여자아동의 모래사진이다. 이 아동은 사촌들로부터 비교적 오 랜 기간 동안 반복적으로 성학대를 당했으며 코로나 발생 이후에 부모가 알게 되어 신고된 사례이다. 그럼에도 불구하고 가해자가 친척이라는 이유로 왜 그러한 일이 일어났는지에 대한 설명이나 사과를 듣지 못했다. 이 아동의 어머니에게는 청결강박이 있었다. 평소에 청 결에 대해 어머니로부터 심한 스트레스를 받았고 이것은 이 아동으로 하여금 인간관계는 옥죄고 억압하는 것이라는 부정적 콤플렉스를 갖게 했다. 이 모래사진은 집안 그리고 등교 하여 교실에 들어가기까지 거쳐야 하는 위생체크 과정을 모든 순서에 따라 매우 세세하고 정리된 모습으로 보여주고 있다. 코로나의 발생은 어머니의 청결강박을 강화 및 정당화시 켰고 불안을 가중시켰으며 아동을 더욱 통제하게 만들었다. 사춘기가 시작된 아동은 자신 의 자율과 독립적인 일상을 주장할 수 있는 근거가 약해졌다. 흥미로운 것은 이 아동이 젖 은 모래를 선택했다는 것이다. 젖은 모래는 손에 묻고 잘 떨어내 지지 않는다. 사진에서 볼 수 있는 바와 같이, 아동은 모래를 만졌고 모래가 묻은 피겨를 옮겼다. 심지어 젖은 모래에 일부 묻혀있는 자동차 피겨도 있다. 그러한 의미에서 이 아동은 어머니의 청결강박과 코로 나로 인해 더욱 강력해진 불안과 두려움을 극복해 가고 있는 과정을 보여주고 있다.

\section{2) 지진 재난 상징}

다음은 코로나 상징은 아니지만 자연 재난 중 하나인 지진에 대한 상징들을 보여주는 모 래사진들이다.

30 대 여성과 40 대 여성의 모래상자에는 지진발생과 신의 관계가 잘 묘사되어 있다. 30 대 여성의 경우 땅을 뒤 흔들고 수천 명이 죽은 지진의 상징인 모래의 거대한 자국 위에 창 조, 출생과 파괴의 힌두신인 시바가 앉아있다. 지진이 일어난 이유도 그리고 그것으로부터 회복하는 것도 모두 시바신의 뜻이라고 했다. 이것은 힌두교 사상을 기반으로 한 표현이다.

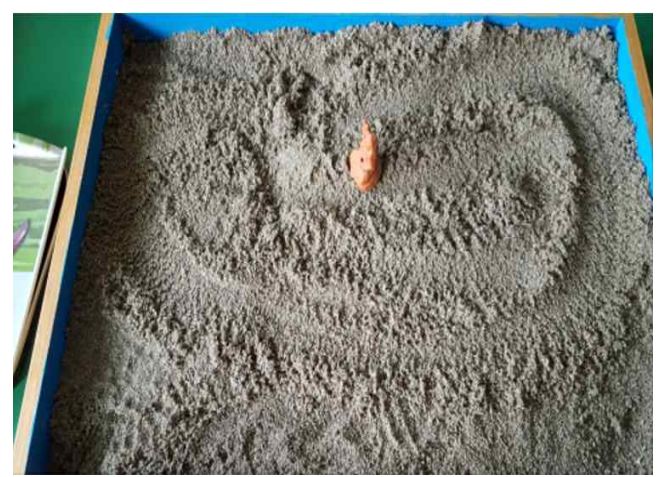

30대 여성 
Journal of Symbols \& Sandplay Therapy, Vol.12 No.2.

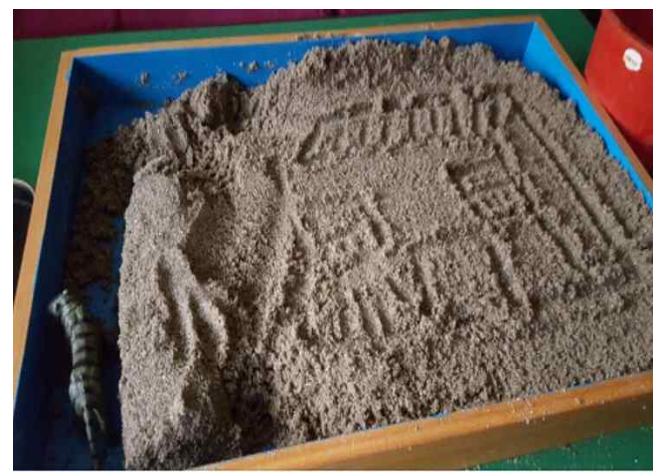

40대 여성

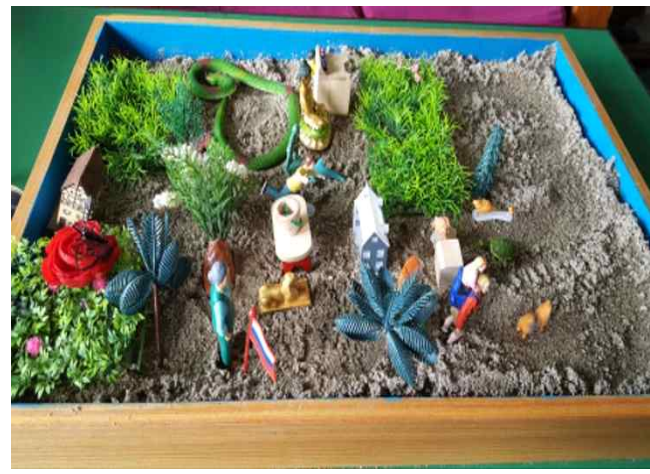

30대 여성

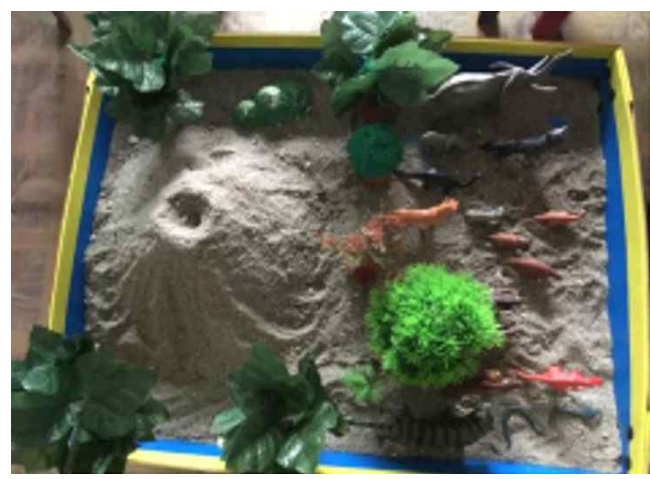

17세 남

40대 여성의 모래상자에는 호랑이의 형태도 지진이 표현되어 있다. 힌두교에서 호랑이는 시바신의 상징이기도 하다. 왼쪽의 호랑이는 언제 다시 나타나서 땅을 뒤흔들지 알 수 없 


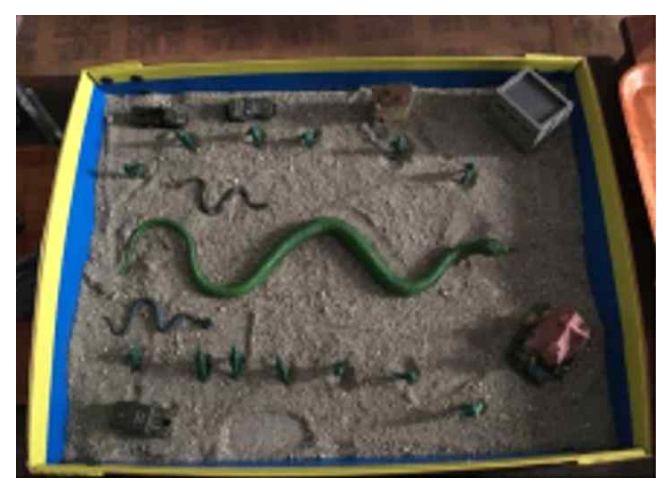

17세 남

는 상태라고 했다. 젖은 모래는 지진에 의해 뒤틀린 것처럼 고르지 않은 상태이지만 그 위 에 손으로 붕괴된 집 대신 앞으로 살아갈 집 즉 그녀의 삶에 대한 청사진을 그렸다.

서로 다른 사람이지만 나이가 같은 이 두 소년 중 한 명은 지진이라는 표현은 사용하지 않았지만 거대한 뱀이 나타나서 군인들이 저지하려고 하고 있다고 했다. 오른쪽 구석에 있 는 건물은 두 동강 나 있는 건물로서 지진의 흔적을 상징한다. 지진이 발생하기 직전에 수 많은 뱀이 땅속에 나오는 것을 목격했다고 생존자들이 증언한 것과 관련 있는 것으로 보인 다. 여기에도 신이 있다. 첫 번째 사진의 소년 역시 지진이라는 표현은 사용하지 않았고 거 대한 화산폭발이 일어나서 동물들이 도망가고 있다고 했다. 당시 강진은 멈추었으나 소규 모의 여진이 계속 되고 있었기 때문에 대규모의 지진이 다시 발생할지도 모른다는 두려움 이 언제 폭발할지 모르는 화산으로 표현된 것으로 보인다. 그와 더불어 본래의 생업과 이 웃이 있었던 곳을 떠나와 생계마저 위협받고 있는 상황 몇 달 이내로 집단 텐트촌에서 마 저 나가야 하는 상황이 언제 터질지 모르는 불안을 가중시킨 것으로 보인다.

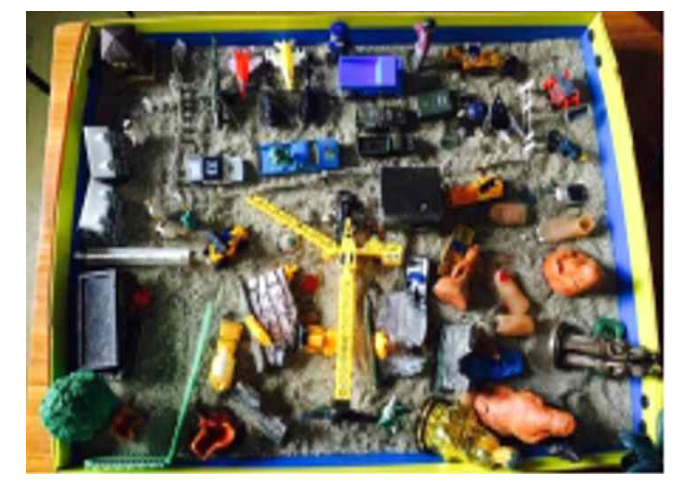

14세 남자 청소년 
Journal of Symbols \& Sandplay Therapy, Vol.12 No.2.

이 남자 청소년의 모래상자는 일견 혼란스럽게 보인다. 그러나 자세히 들여다 보면 지진 의 피해로 무너진 집들이 있고 그것을 회복하기 위한 공사가 이루어지고 있으며 자동차들 을 일렬로 정리한 것은 지진으로 붕괴된 사회의 질서회복을 상징하는 것으로 보인다. 역시 이 사진에도 힌두교의 여러 신들이 등장한다. 네팔은 힌두교와 불교신자가 주를 이루는 사 회이며 전통적인 종교실천이 다른 문화권에 비해 강하게 남아 있는 곳이다. 지진을 일으킨 장본인이자 지진으로부터의 회복을 가능케 하는 것도 신이기 때문에 이들의 모래상자에는 신상이 자주 나타났다. 더 중요한 것은 모래놀이치료를 통해 회복의 놀이를 하고 있다는 것이다. 개인내적 측면에서 지진으로 인한 불안, 집이 다 무너져 임시 텐트촌에 살아야 하 는 불안정성과 불편함에도 불구하고 그것을 극복하고 회복하려는 시도가 놀이로 나타나고 있는 것이다.

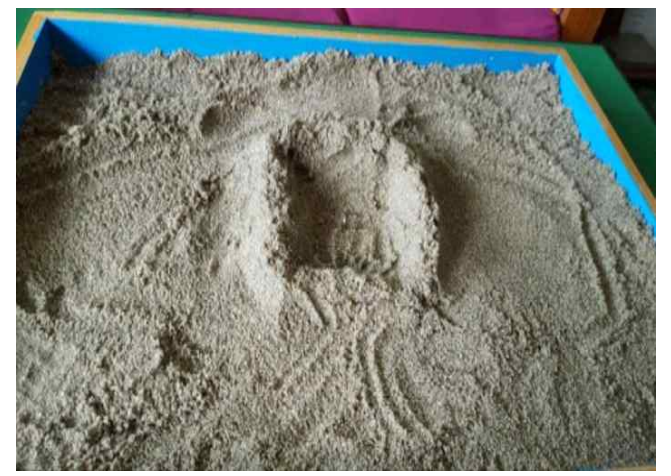

30대 여성 가정폭력 피해자

이 30 대 여성은 집이 완전히 완파 되었고 국가가 마련해준 집단 텐트촌도 아닌 작은 텐 트에서 물과 화장실도 없이 살아가고 있는 여성이다. 그녀의 남편은 오래 전부터 가족을 부양하지 않고 폭력을 휘둘렀다. 그녀의 꿈은 자신만의 집을 짓고 자녀들과 사는 것이었다. 네팔의 도시와 동네 그리고 개인의 집에는 작은 신전이 무수히 많다. 그들은 특정 절기뿐 아니라 자신의 불운과 소원을 신전에 가서 신께 비는 일상의 문화가 있다. 모래가운데 미 완성인 채로 있는 저 집은 그러한 작은 신전이자 폭력에 시달리지 않고 살 수 있는 그녀만 의 신성한 집이다. 즉 물리적 공간이면서 동시에 마음의 평화다. 그녀는 모래상자에서 스스 로 신성한 종교의례를 했다고 할 수 있다.

재난, 외상, 빈곤, 가족/지인의 죽음, 폭력에도 불구하고 인간은 얼마나 강인한 존재를 다 시 돌아보게 하는 모래장면들이다. 이러한 작업을 언어상담으로만 한다면 이러한 결과를 얻을 것이라 상상하기가 쉽지 않다. 모래놀이치료자에게는 상징과 이미지라는 위대한 수단 이 있다. 
심혼(psyche)이 만들어내는 상징이미지는 상상에 불과한 것이 아니다. 상상에 불과하다면 치료 접근으로 사용될 수 없다. 이것을 증명하는 한 가지 실험 예를 들 수 있다. 미국 Emory 대학의 Gregory Berns는 2013년에 열두 명의 대학생을 대상으로 저녁마다 소설을 읽 게 하고 다음 날 $\mathrm{fMRI}$ (기능성 뇌자기영상장치)로 뇌를 촬영했고 또한 소설 읽기가 끝난 5 일 후에도 fMRI로 뇌를 촬영했다. 그 결과 실험이 끝난 후에 조차도 소설읽기의 효과가 지속 되는 것 발견했다. 실험결과 언어의 감수성을 관장하는 뇌 부위인 왼쪽 측두엽(left temporal cortex)의 신경회로가 활성화 되었고 더 중요한 결과는 뇌의 1 차 감각운동영역인 중심구 (central sulcus) 역시 활성화 되었다는 것이다. Berns에 의하면, 뇌의 중심구(central sulcus) 영역 은 달리는 동작을 생각만 하고 있어도 달리는 신체동작과 관련된 신경세포들이 활성화되는 영역이다. 소설을 읽을 때 이 뇌 부위가 활성화 된다는 것은 마치 소설의 주인공인 된 것 처럼 느낀다는 것을 의미한다고 한다(연합뉴스 2013년 12월 27일). 훌륭한 주인공이 나오는 소설을 읽으면 자신이 마치 그 주인공이 된 것 같은 느낌을 갖는데 이것이 실제 생물학적 으로도 일어나고 있다는 것이다. 강조할 필요도 없이 소설은 상상인데 모래놀이치료 모두 손으로 하는 상상 작업이어서 그 효과는 비슷할 것으로 가정할 수 있다. 상상을 작업하는 것이 실제로 우리의 삶을 변화시킨다는 것을 신경생물학적으로 입증해준 것이라고 할 수 있다.

\section{II. 결 론}

과거의 전통사회에서 했던 것처럼 마스크로 탈 난 얼굴을 가릴 것이 아니라 자신의 진짜 문제인 '탈'을 쓰고 '신'께(즉 자신의 내면에 직면하며) 그것을 보여주며 신을 기쁘게 하여 탈이 지나가게 해야 하는 시대에 우리는 살고 있다. 우리 각자와 인류의 시대적 탈이 무엇 인지 진정으로 보아야 하는 시대에 치유자로서 모래놀이치료자는 모래놀이에서 '우리의' 내 담자와 우리 자신을 위해 탈춤굿놀이 또는 탈춤굿놀을 할 것을 요청 받고 있다. 그것을 할 때, 팬데믹으로 인한 원형적 그림자가 우리의 그림자 속에 있는 부정적 컴플렉스와 연합하 여 인격이 무너지거나 자아가 기능을 할 수 없는 상태가 되는 것을 막을 수 있을 것이다. 탈춤굿놀이를 했던 사람들이 진정한 탈로 자신의 문제가 무엇이었는지를 진심으로 보여줌 으로써 신께 겸허함을 보이는 것처럼 치료자인 우리도 우리 자신의 진정한 탈을 쓰고 자연 과 우리 본성의 자연 앞에 겸손해질 필요가 있다. 대단한 연습을 통해서 공연을 하는 춤이 아니라 탈춤의 춤은 마음과 몸이 자발적으로 추는 춤이다. 즉 놀이인 것이다. 상상을 기본 으로 하는 놀이, 춤은 상상에 그치는 '쓸데없는' 짓이 아니라 상상은 우리의 심혼을 표현하 며 Berns박사의 실험결과가 보여주듯 상상은 우리의 마음과 감정을 바꾸는 형태로 우리의 
Journal of Symbols \& Sandplay Therapy, Vol.12 No.2.

현실 삶에 영향을 미친다. 그럼에도 불구하고 우리는 주변사람들의 코로나로 인한 시대적 죽음을 경험한다. 그렇다면 우리는 삶에서 죽음이 무엇을 의미하며 죽음 후의 삶은 어떤 것인지 놀이함으로써 또는 놀이해냄으로써 언제 닥칠지 모르는 주변사람들의 죽음 더 나아 가 자신의 죽음 그리고 죽음 후의 삶에 대한 준비를 해야 한다. 팬데믹 시대에 불안과 공 포를 견디지 못해 심리치료자를 찾아오는 내담자들은 세상 멸망할 것 같은 두려움을 느끼 며 죽음은 모든 것의 끝이라고 생각한다. 그러나 Jung은 "인간은 그의 사후의 생에 관한 의 견을 만드는 데 혹은 거기에 관한 서술을 하는데 최선을 다 했다는 것을 비록 자신의 무능 력을 고백하면서라도 증명할 수 있어야 한다(Jung, 1963/2003, p. 344)"고 자서전에서 언급했 다. 당연히 이것은 물리적 죽음뿐 아니라 심리적 죽음에도 해당할 것이다. 심리적으로 죽음 의 공포를 느끼더라도 우리는 그것이 끝이 아니라는 것과 그것이 의미하는 것에 대해 생각 하는데 최선을 다해야 할 것이다.

\section{참고문헌}

김성민 (2017). 분석심리학과 문학: 예술에 대한 프로이드와 융의 태도의 차이. 신학과 실천,

53, 217-254. doi: http://dx.doi.org/a0.14387/jkspth.2017.53.217

대한민국 자살률 $\mathrm{OECD} 1$ 위 ‘오명'...인구 10 만명 당 266명. 데일리경제(2020년1월20).

Retrieved from biz.newdaily.co.kr/site/data/html/2020/06/01/2020060100129.html 이부영 (1986). 한국설화에 나타난 치료자 원형상: 손님 굿 무가를 중심으로. 심성연구, 1 , $5-27$.

이부영 (2012). 한국의 샤머니즘과 분석심리학: 고통과 치유의 상징을 찾아서. 서울: 한길사.

이세화, 장미경 (2020). The effect of group sandplay therapy on psychological health and resilience

of adolescent survivors of Nepal earthquake). 상징과 모래놀이치료, 11(2), 45-78.

임재해 (1999). 하회탈 하회탈춤. 서울: 지식산업사.

장미경 (2015). 모래놀이치료에서 탈의 원형적, 심리학적 상징성. 상징과 모래놀이치료, 5(2), $1-10$.

장미경 (2017). 분석심리학적 모래놀이치료. 서울: 학지사.

How a book really can change your life: Brain function improves for DAYS after reading a novel

(Mail Online 27 Dec. 2013). Retrieved from

https://www.dailymail.co.uk/sciencetech/article-2529855/How-book-really-change-life-Brain-function-i mproves-DAYS-reading-novel.html

Kawai, T. (2019). Big stories and small stories in the psychological relief work after the earthquake 
disaster: life and death. In L. Huskinsons \& M. Stein (ed.), Analytical psychology in a changing world: The search for self, identity and community. London/New York: Routledge.

Jacobi, J. (2013). The psychology of C. G. Jung. New York: Routledge.

Jung, C. G. (1935). Tavistock lectures. CW18, Bollingen Series XX. Princeton, NJ: Princeton University Press.

Jung, C. G. (1933/2017). Modern Man In Search of a Soul. Boston, MA: Mariner Books.

Jung, C. G. (1970). Civilization in transition ( $2^{\text {nd }}$ ed.).Princeton,NJ:PrincetonUniversityPress.

Jung, C. G. (1970). Definitions. In C. G. Jung, Psychological types. CW 6, Bollingen Series XX. Princeton, NJ: Princeton University Press.

Jung, C. G. (1981). On the nature of psyche. In C. G. Jung, The structure and dynamics of the psyche $\left(2^{\text {nd }}\right.$ e. $) . C W 8$, BollingenSeriesXX.Princeton,NJ:PrincetonUniversityPress.

Jung, C. G. (1990a). Symbols of transformation ( $2^{\text {nd }}$ ed.).CW5,BollingentSeriesXX.Princeton,NJ:Princeton Jung, C. G. (1990b). Archetype and the collective unconscious ( $2^{\text {nd }}$ ed.). CW9, Bollingent Series XX. Princeton, NJ: Princeton

Jung, C. G. (1993). Psychologie und Alchemie, Psychology and alchemy, Bollingen Series XII. (Tr. Rascher Verlag). Princeton, NJ: Princeton University Press. (1968).

Jung, C. G. (2003). 회상, 꿈 그리고 사상. Dreams, memories and reflections (A. Jaffe 엮음, 이부영 역). 1963.

Jung, C. G. (2004). 인간과 문화. Mensch und Kulture (C. G. 융저작번역위원회 역). 서울: 솔출판 사. (1955).

Jung, C. G. (2009). The Red Book: Liber Novus. Tr. M. Kyburz, J. Peck, S. Shamdasani. (ed.). New York: W. W. Norton.

Kalff, D. (1980). Sandplay: A psychotherapeutic approach to the psyche. Cloverdale, CA: Temenos Press Leavy, P. (2020). Method meets art: Arts-based research practice ( $3^{\text {rd }}$ ed.). NewYork: GuilfordPress.

Sedgwick, D. (2001). Introduction to Jungian psychotherapy: The therapeutic relationship. New York: Brunner-Routledge.

Stein, M. (2020a). Interview with Murray Stein for Pacifica Graduate Institute.

https://www.pacificapost.com/interview-with-murray-stein 접속 2020년 7월 8일

Stein, M. (2020b). A World Shadow: COVID 19. Retrieved from

https://chironpublications.com/a-world-shadow-covid-19/

Taborada, F. (2020). Breath and the Asphyxiating Life in Time of the Coronavirus. C. G. Jung Institute of Chicago.

https:/jungchicago.org/blog/freddie-taborda-breath-and-the-asphyxiating-life-in-time-of-the-coronavirus/ 
Journal of Symbols \& Sandplay Therapy, Vol.12 No.2.

Wilber, K. (2000). Integral psychology: Consciousness, spirit, psychology, therapy. Boston, MA: Shambhala Publication Inc.

투고일 : 2021. 09. 30

수정인 : 2021. 11. 27 게재확정일 : 2021. 12. 06 